\title{
Algumas considerações em torno ao imbroglio Posada: quando as imagens não ilustram os textos ${ }^{1}$
}

\author{
Natally Vieira Dias ${ }^{2}$
}

\begin{abstract}
Resumo: A impressionante obra gráfica do gravurista mexicano José Guadalupe Posada (1852-1913) - dentro da qual se destacam as famosas calaveras alegres e dançantes - tem chamado a atenção de estudiosos há décadas. Umas das questões mais controversas nesses estudos diz respeito às relações do artista com a política, sendo que existe uma espécie de imbroglio envolvendo, de um lado, a visão de um Posada revolucionário e precursor da Revolução Mexicana e, de outro, a imagem de um Posada reacionário e porfirista. $\mathrm{O}$ objetivo deste trabalho é matizar essas duas versões dicotômicas e propor um novo olhar sobre as relações da obra de Posada com o universo político de sua época partindo da análise de algumas de suas gravuras publicadas na imprensa popular mexicana, principalmente a partir do acirramento da oposição à ditadura de Porfirio Díaz até as últimas obras do artista, falecido em 1913. A análise toma como base a proposta de Guillermo Sunkel (2016 [1985]) sobre as "matrizes culturais" e as concepções de Mikhail Bakhtin (1993 [1965]) a respeito do papel subversivo do "riso popular".
\end{abstract}

Palavras-chave: José Guadalupe Posada; Política; Imprensa Popular Mexicana.

\section{Some considerations regarding the Posada imbrloglio when the images do not illustrate the texts}

\begin{abstract}
The impressive graphic work by Mexican engraver José Guadalupe Posada (1852-1913) - whose famous cheerful and dancing calaveras (skulls) stand out - has drawn scholars' attention for decades. One of the most controversial issues in these studies concerns the artist's relationship with politics, since there is a type of imbroglio involving, on the one hand, the vision of a revolutionary Posada, who would have been a precursor of the Mexican Revolution and, on the other hand, the image of a reactionary and Porfirian Posada. The aims of the current study are to question these dichotomous versions of Posada and to propose a new look over the relationship between his work and
\end{abstract}

\footnotetext{
${ }^{1}$ A publicação deste artigo seria impossível sem o apoio de várias pessoas que me ajudaram a conseguir os direitos de reprodução das ilustrações de Posada. Quero agradecer especialmente ao prof. Luciano Ramírez Hurtado (UAA) pelas imagens dos acervos dos museus de Aguascalientes, Museo José Guadalupe Posada e Museo Nacional de la Muerte, e por me colocar em contato com o sr. Mercurio López Casillas, quem, muito gentilmente, me cedeu o direito de reprodução de obras de sua coleção. Agradeço também à prof ${ }^{a}$ Lilia Vieyra Sánchez (UNAM), que facilitou meu acesso às imagens pertencentes à Hemeroteca Nacional de México, bem como ao sr. Andrés Blaisten, que me cedeu o direito de reproduzir imagens de sua coleção que constam no Museo Blaisten.

${ }^{2}$ Doutora em História, professora do Programa de Pós-Graduação e do Departamento de História da Universidade Estadual de Maringá (UEM). E-mail: natyvdias@gmail.com.
} 
the political scenario of his time, based on the analysis of some of his engravings published by the popular Mexican press, from the fierce opposition to Porfirio Díaz's dictatorship to the latest works of the artist, who died in 1913. The analysis is based on Guillermo Sunkel's (2016 [1985]) ideas about "cultural matrices" and on Mikhail Bakhtin's (1993 [1965]) concept of the subversive role played by "popular laughter".

Keywords: José Guadalupe Posada; Politics; Popular Mexican Press.

Artigo recebido em: 05/07/2020

Artigo aprovado para publicação em: 06/05/2020

\section{Uma breve trajetória de Posada, um artista popular}

O gravurista José Guadalupe Posada (1852-1913) é um dos mais reconhecidos artistas mexicanos e possui uma imensa obra gráfica em meio a qual se destacam as imagens caricaturescas e/ou satíricas publicadas principalmente em veículos da imprensa popular, como as chamadas hojas sueltas e periódicos da prensa obrera de a centavo. ${ }^{3}$ Dentro desse universo pictórico, sobressaem-se as imagens de calaveras alegres, dançantes e sorridentes, que conquistaram o público da época e, até hoje, fazem o artista mexicano conhecido em todo o mundo, principalmente por sua calavera catrina (imagem 1), que tornou-se o ícone feminino mais conhecido do México depois da Virgem de Guadalupe. (BARAJAS DURÁN, 2009, p. 100)

\footnotetext{
${ }^{3}$ As chamadas hojas sueltas, ou volantes, eram impressos "soltos", publicados em uma única página e sem periodicidade. A prensa obrera de a centavo corresponde a impressos populares, que eram vendidos a poucos centavos, e estavam ligados à classe trabalhadora.
} 


\section{Imagem 1 - La calavera catrina}

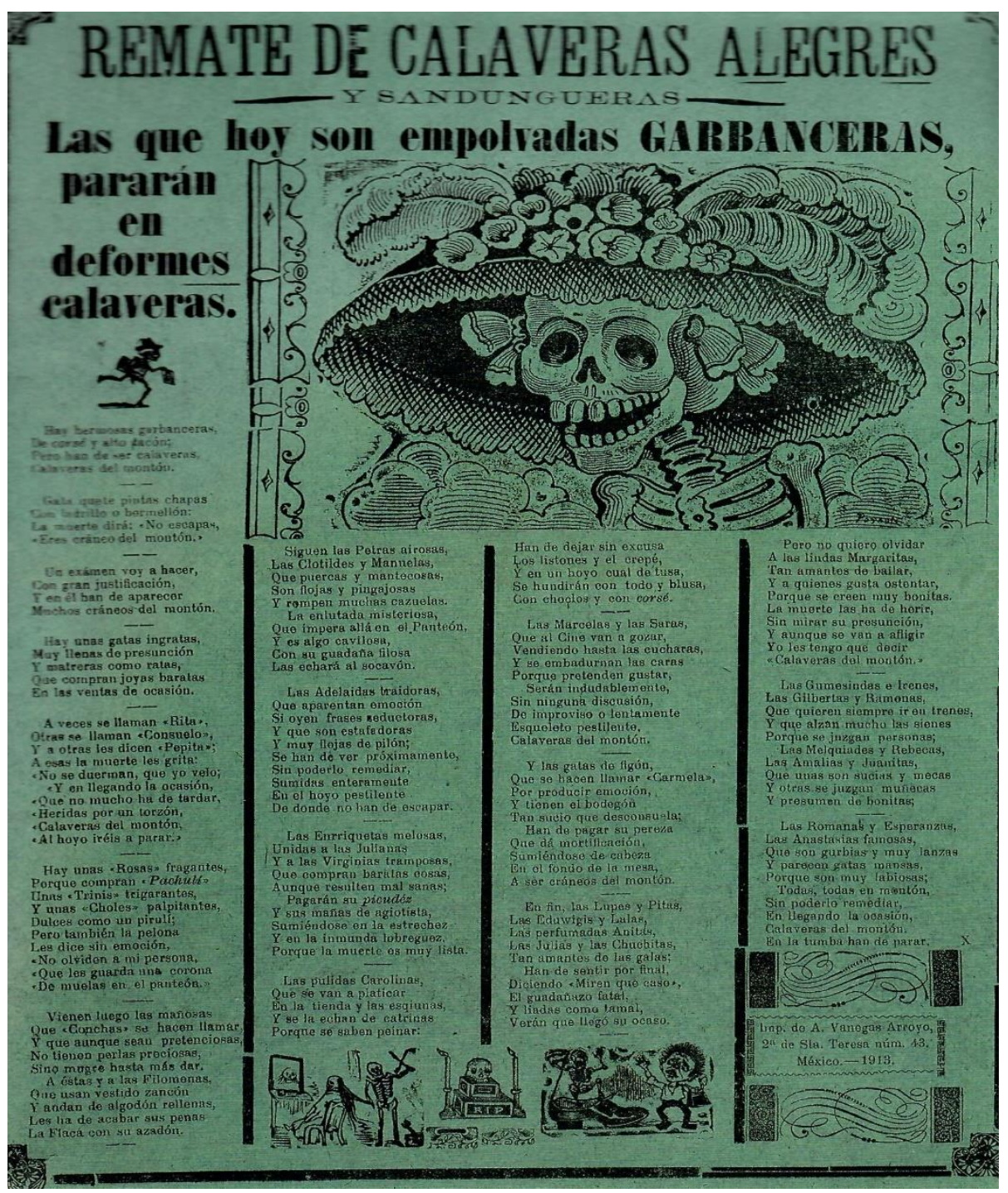

Remate de calaveras alegres y sandungueras (hoja suelta).

México, D.F., Imprenta de Antonio Vanegas Arroyo, 1913.

Imagem do acervo do Museo José Guadalupe Posada, Instituto Cultural de Aguascalientes.

O sucesso alcançado pelo trabalho de Posada frente ao público de sua época, o que ocorreu sobretudo por meio de impressos populares, relaciona-se bastante à sua capacidade de expressar o universo cultural desses setores, algo que, em grande medida, vincula-se à sua própria origem. Muito embora, como mostram Alain Luévano Díaz e Luciano Ramírez Hurtado (2015), o gravurista não tenha se formado à margem da instrução formal, mas frequentado, em sua juventude, a Academia Municipal de Dibujo 
em sua cidade natal, Aguascalientes, Posada possuía uma origem popular, advindo de uma família de oito irmãos, cujo pai era padeiro. Com cerca de 16 anos, frequentava a Escuela para Adultos de Aguascalientes para completar sua instrução de leitura e escrita, aos 17 ingressou na Academia de Dibujo e, ao mesmo tempo, já começou a trabalhar como artesão junto ao importante impressor José Trinidad Pedroza. (LUÉVANO DÍAZ; RAMÍREZ HURTADO, 2015)

O início da careira de Posada ocorreu durante a República Restaurada (1867-1876) como caricaturista em órgãos da imprensa de combate vinculada aos liberais, como o periódico satírico El Jicote, que era editado pelo impressor para quem trabalhava. Em 1872, ambos Trinidad Pedroza e Posada instalaram uma imprensa litográfica na cidade de León, estado de Guanajuato. No ano seguinte, o impressor retornou a Aguascalientes e Posada assumiu o negócio em Guanajuato, onde acabou se estabelecendo e casando-se com uma moça da região. Mas, em 1888, uma terrível inundação varreu a cidade, forçando o gravurista a migrar. O artista foi, então, para a Cidade do México, onde passou a colaborar com a prestigiada revista La Patria Ilustrada, editada por Irineo Paz, que possuía um bom "olho para detectar os caricaturistas de talento." (BARAJAS DURÁN, 2009 , p. $38 ; 50 ; 73)$

Pouco tempo depois, a partir de 1891, o gravurista passou a ilustrar os papeles de Antonio Vanegas Arroyo, que possuía a mais importante imprensa popular mexicana da época. Essas hojas populares recobriam um extenso conjunto de impressos, destacandose as versões hojas sueltas com "oraciones, cuentos, adivinanzas, canciones populares, [...] la lotería, charros contrabandistas, comedias para títeres, versos para payaso, los corridos que devendrían legendarios y, desde luego, las famosísimas 'calaveras' [dibujadas por Posada]." (MORENO VILLARREAL, 2003)

Embora a caricatura política tenha sido uma atividade importante em sua trajetória, desde os inícios em Aguascalientes, mas também colaborando com a prensa obrera de a centavo na capital mexicana, a principal fonte de renda e reconhecimento de Posada enquanto artista foram, de fato, as ilustrações das hojas sueltas da imprensa de don Venegas. Certamente, por sua própria origem nas classes menos abastadas, o artista conhecia os recursos expressivos, a linguagem, capaz de interpelar os estratos inferiores 
da sociedade. Não por acaso, suas gravuras rapidamente conquistaram o público e alcançaram grande sucesso de vendas. Por sua incrível capacidade de expressar aspectos do cotidiano e do imaginário das classes populares "Posada se fue convirtiendo en la gran atracción de la editorial", que começou a decair após sua morte. (WESTHEIM, 2003; SPECKMAN GUERRA, 2005, p. 395)

José Guadalupe Posada colaborou com a imprensa de Vanegas Arroyo até o fim de sua vida, vindo a falecer em 1913, após já ter ficado viúvo e perdido seu único filho. A historiadora da Arte Raquel Tibol expressa de forma eloquente o lugar ocupado por Posada enquanto um artista popular e também os elementos que marcaram sua morte e acabaram se tornando, eles próprios, representativos do lugar social, ao mesmo tempo sublime e ordinário, que caracterizaram sua carreira como artista:

\begin{abstract}
Posada no fue un ente anónimo; casi toda su producción está firmada con rúbrica inconfundible, y la divulgación de su obra fue incomparablemente mayor que la de sus contemporáneos académicos [...] ligados a Europa por unos vasos comunicantes que ni siquiera se les ocurría actualizar, y a los que se aferraron parapetados medrosamente en la Escuela Nacional de Bellas Artes, situada a unos pasos del taller de Posada [...]. Fue, en la capital del país, un pobre más que caló la realidad de su hora desde la atalaya del artesano. A su entierro no asistió ni Antonio Vanegas Arroyo, su principal editor, quien vino a enterarse de la desgracia tres días después de que Posada descansaba en una fosa de sexta clase. Transcurridos los siete años reglamentarios nadie reclamó sus restos y el genial artista pudo por fin descansar a gusto, cómodamente entre sus iguales, en la ilustre fosa común. (TIBOL, 2002)
\end{abstract}

\title{
Posada e a questão da imprensa popular
}

Em 1880, quando Antonio Vanegas Arroyo fundou, na Cidade do México, uma imprensa dedicada à produção de impressos populares ilustrados, não se tratava exatamente de uma novidade. As hojas sueltas, ou volantes, existiam desde a Colônia e, pelo menos desde meados do século XIX, os grabados já faziam parte desse tipo de publicação. (BONILLA, 2005, p. 416) O aspecto inovador da imprensa popular de fins daquele século, da qual o empreendimento de Vanegas é emblemático, só se torna evidente quando observado dentro do contexto mais amplo das transformações 
socioculturais que marcaram o México, bem como a maior parte da América Latina, entre fins do século XIX e inícios do XX.

O desenvolvimento dessa nova imprensa popular, constituída enquanto uma imprensa-empresa, caracterizada pela produção massiva de impressos, vendidos a poucos centavos e voltados para as camadas semi (ou mesmo não) letradas da população, foi parte do mesmo processo de formação de uma "grande imprensa", 4 tecnicamente modernizada, cuja maior expressão foi o surgimento de grandes jornais diários que se tornaram um dos principais ícones da modernização latino-americana.

No caso da imprensa ilustrada, sobretudo a veiculação de caricaturas, no caso do México sua proliferação remonta aos "periódicos polêmico-burlescos", que floresceram a partir de meados do século XIX, ligados às disputas políticas. Ao comentar sobre esse tipo de publicação no contexto de fins daquele século, a historiadora Laura Suárez de la Torre (2005) destaca que esse foi um "género que gozó de la aceptación del público lector e inauguró otro tiempo dentro de la prensa periódica", processo que esteve muito relacionado ao também "nиevo tiempo que representó la larga permanencia de Porfirio Díaz en el poder y que propició el desarrollo de múltiples empresas [editoriales]". (DE LA TORRE, 2005, p. 23)

A autora aponta o debate político como o cerne para o desenvolvimento de periódicos e folhetos, inclusive os ilustrados, mas destaca que a segunda metade do século XIX mexicano foi marcada por um panorama de múltiplos e diversificados tipos de impressos, que estiveram relacionados a diferentes interesses, não apenas de grupos políticos, mas também "religiosos, literários" etc., interessados em publicizar suas ideias. Ainda segundo de la Torre, essa diversidade revela os interesses de "un público lector que debió incrementarse día a día", mas también demonstra que "en un país con gran

\footnotetext{
${ }^{4} \mathrm{O}$ termo "grande imprensa" refere-se aos grandes jornais-empresas surgidos no contexto da modernização na América Latina, caracterizados pela modernização das técnicas de impressão, que permitiam a produção rápida de grandes tiragens e, consequentemente, tornava os preços mais acessíveis. Os grandes jornais diários, de caráter informativo, passavam a se caracterizar também pela agilidade na captação e distribuição de informação, sobretudo por meio do telégrafo, além do significativo espaço conferido à publicidade. Como destaca Nelson Werneck Sodré em seu clássico livro sobre a história da imprensa no Brasil - e isso vale para o contexto latino-americano: "o jornal será, daí por diante, empresa capitalista, de maior ou menor porte". (SODRÉ, 1966, p. 315)
} 
índice de analfabetismo, el interés por la lectura se manifestó a través de innumerables proyectos editoriales." (DE LA TORRE, 2005, p. 25)

Em geral, ao tratar de impressos populares de fins do século XIX, como os produzidos pela imprensa-empresa de Vanegas Arroyo e ilustrados por Posada, a historiografia tem prestado bastante atenção ao aspecto de seu público consumidor. Sabemos muito, por exemplo, sobre o público atingido pelas hojas sueltas de Vanegas Arroyo, sobre o consumo desses impressos e até mesmo sobre a dinâmica que envolvia sua distribuição em áreas rurais, distantes da capital. Como é perceptível, pela linguagem, temas e formato, as hojas se dirigiam aos baixos estratos sociais. Helia Hemma Bonilla (2005) nos informa que, ocasionalmente, as próprias imagens dos impressos revelam seu público e inclusive dão indícios do lugar que ocuparam na vida dos setores populares, ao mostrar, por exemplo, as estampas desses impressos coladas em paredes de habitações humildes. (BONILLA, 2005, p. 118).

Sobre as distintas formas de acesso ao conteúdo dessas hojas, Elisa Speckman Guerra (2001) destaca que "los vendedores ambulantes pregonaban el contenido de la publicación y en ocasiones cantaban los corridos. [...] Por tanto, el contenido de los escritos no sólo llegaba a los individuos que adquirían y leían el texto, sino también a sus oyentes." (SPECKMAN GUERRA, 2001, p. 70). A respeito da ampla circulação dos papeles da imprensa de Vanegas, Paul Westheim (2002) afirma o seguinte:

\footnotetext{
Vendedores ambulantes las vendían en todas partes de la República, hasta en los rincones más apartados, en el campo y en las ciudades, delante de las iglesias, por los mercados, en las ferias. Para los compradores, en su mayor parte analfabetos, lo más interesante era la ilustración, que les daba una idea mucho más viva del suceso sensacional que los versos ramplones. (Westheim, 2002)
}

Esta última citação aponta para uma possível independência de "leituras" entre imagem e texto por parte do público (letrado e não letrado) das hojas populares. Esse é um ponto essencial para pensar a intervenção do artista Posada nesses impressos e voltarei

\footnotetext{
${ }^{5}$ Os índices de analfabetismo no México entre fins do século XIX e inícios do XX passavam de 70\% da população, de acordo com dados apresentados por Guerra (2003, p. 416), com base nos censos mexicanos da época.
} 
a ele mais à frente. Por ora, o que quero destacar é que tanto Westheim quanto os outros autores consultados nos colocam diante de um amplo e heterogêneo possível público consumidor (leitores, ouvintes ou simples apreciadores visuais) das hojas volantes da imprensa de Vanegas, praticamente todas ilustradas por Posada. Trata-se de um público, sem dúvida, formado pelas classes populares, mas que perpassava distintos setores, desde grupos alfabetizados, mas ainda não bem inseridos no universo da leitura, localizados no meio urbano ou semi-urbano da Cidade de México e seus arredores, até camponeses analfabetos que viviam em pueblos distantes.

Embora o mapeamento do público ao qual se dirigiam essas publicações massivas voltadas às classes populares seja algo extremamente importante, isso representa apenas uma parte do esforço de compreender o papel que essas hojas cumpriam socialmente. Outra parte fundamental consiste em identificar os grupos produtores e situar as publicações em termos de suas condições de produção, o que significa inseri-las no âmbito da modernização que, conforme já mencionado aqui, atingiu a imprensa como um todo em finais do século XIX. Essa dimensão, em geral, tem sido pouco explorada nos trabalhos historiográficos e isso tem implicado um problema analítico de dimensões significativas.

Ao se concentrar na questão do público destinatário dos impressos massivos populares e levar em conta que as publicações tinham um objetivo eminentemente comercial, os estudiosos tendem a concluir que esses impressos se tratavam simplesmente "de una literatura hecha con el fin de venderse" e, portanto, "la interpretación, el dibujo y la moraleja extraída de los crímenes pasionales [por ejemplo] debió coincidir con las ansias informativas, las simpatías, los prejuicios, los temores y la postura de los lectores." (SPECKAM GUERRA, 2001, p. 70-71)

O problema desse argumento é que induz a pensar que havia uma correspondência simples e direta entre o conteúdo dos impressos e as percepções e valores compartilhados por seus destinatários, como se as hojas volantes fossem meramente um espaço/meio de expressão do imaginário popular. Essa interpretação deixa de levar em conta uma questão fundamental: justamente pelo fato de esses impressos populares terem se tornado 
mercadorias, produzidas por imprensas-empresas capitalistas, a distância entre seus produtores e consumidores tendia a se ampliar.

No caso das hojas publicadas pela imprensa de Vanegas Arroyo, até mesmo os corridos, considerados uma das maiores expressões da literatura popular mexicana, eram escritos pelo próprio dono da empresa, que era também o editor dos impressos, auxiliado, muitas vezes, por seu filho Blas Vanegas Arroyo. (SPECKAM GUERRA, 2001, p. 69) Isso permite supor que esses papeles, para além de uma "voz popular", deviam expressar também a visão de seus editores - que eram, na verdade, os donos da imprensa-empresa -, embora em linguagem e formato populares. Esse elemento é particularmente importante no caso de impressos que se relacionam mais diretamente ao âmbito do político e apresenta-se como algo central para compreendermos a intervenção política de Posada por meio desses impressos, conforme desenvolvemos na sequência. Antes, vale destacar que o próprio Posada, com seu olhar sempre perspicaz, não deixou de perceber e expressar sua percepção do lugar social de don Vanegas - muito diferente do ocupado pelos consumidores de seus impressos -, ao representá-lo, sob a tradicional forma de uma calavera, com os bolsos transbordantes de dinheiro, derivado, certamente, de sua imprensa-empresa de impressos populares. (Imagem 2) 


\section{Imagem 2 - Calavera de Antonio Vanegas Arroyo}

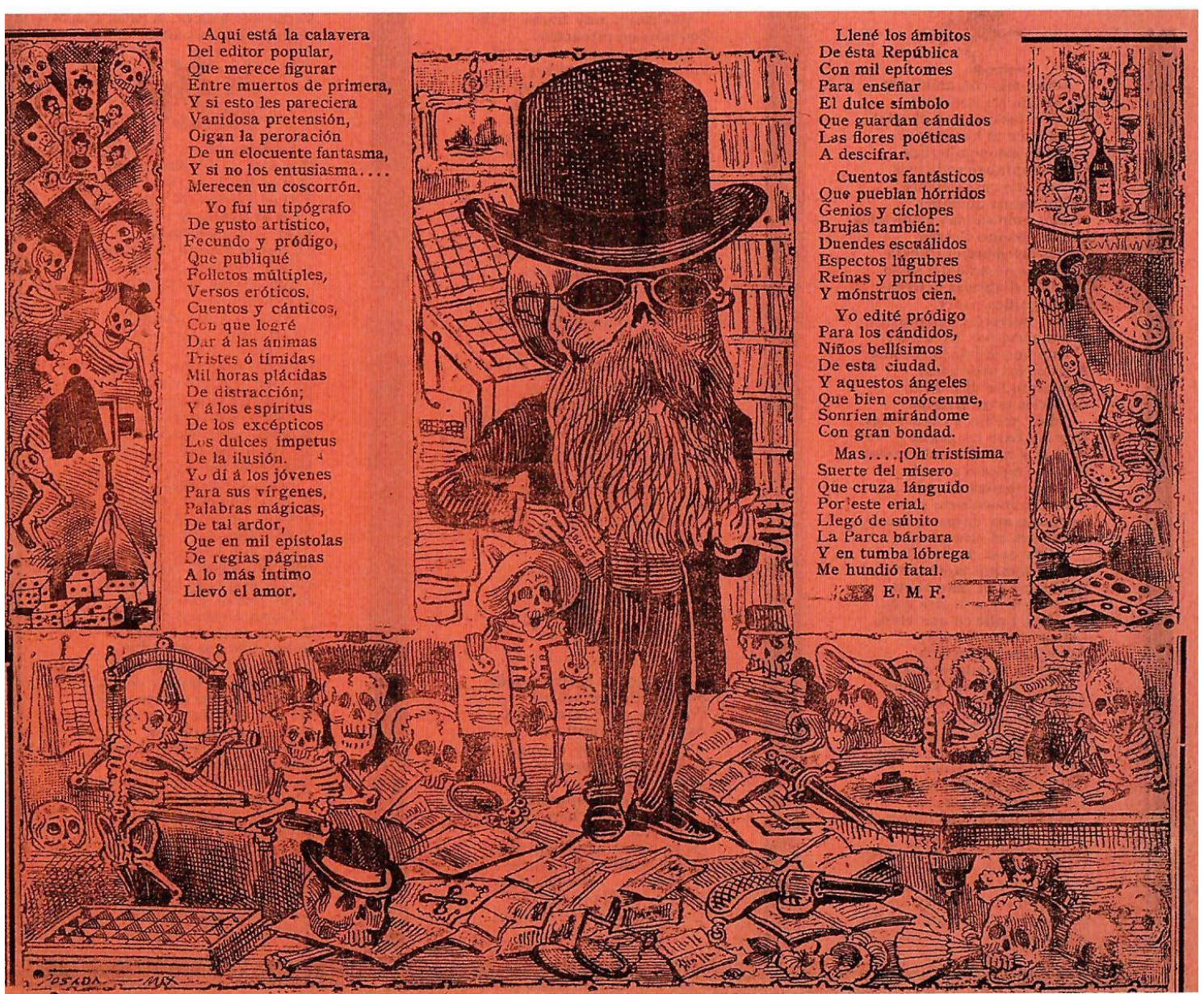

Aquí está la calavera del editor popular A. Vanegas Arroyo (hoja suelta).

México, D.F.; Imprenta de Antonio Vanegas Arroyo, 1902.

Imagem da Colección Mercurio López Casillas.

\section{A dimensão política da obra de Posada: entre "mitoteros" e caça-mitos}

Conforme destacado no início deste artigo, a questão da posição política de Posada é uma das mais controversas - e, em nossa perspectiva, mais instigantes - nas análises da obra do artista. Durante muito tempo, a visão predominante foi a difundida pelos muralistas mexicanos - particularmente Diego Rivera e José Clemente Orozco -, que erigiram a imagem de um Posada heroico, crítico e revolucionário, propriamente um 
precursor da Revolução Mexicana. ${ }^{6}$ Orozco, que permaneceu no México durante a guerra civil revolucionária e, segundo afirma, teve contato pessoal com o artista popular, produziu, em sua Autobiografía, um relato que podemos chamar de fundador do "mito" em torno de Posada. Muito embora o muralista não relacione diretamente o artista popular com o acontecer político da época (pré-revolucionária), ele atribui ao "maestro Posada" o "primeiro estímulo" que "despertou [sua] imaginação" e forjou sua "primeira revelação da existência da arte da pintura." (OROZCO, 2002 [1945] p. 11-12) Como sabemos, para o muralista, expressão artística e intervenção social e política não se separavam.

No mesmo relato, Orozco descreve Posada como um personagem que "trabajaba a la vista del público, detrás de la vidriera que daba a la calle", o que deixava Orozco na época um estudante que passava todos os dias por essa rua a caminho da escola absolutamente "encantado" ao observar o trabalho do artista popular. Essa descrição do muralista acabou se tornando muito relevante para a construção da imagem do Posada revolucionário. Inspirado nela, nos anos 50, o gravurista Leopoldo Méndez construiu uma das mais emblemáticas imagens visuais do Posada progressista. ${ }^{7}$ Nela, o artista popular olha atentamente o acontecer social nas ruas através da janela de sua mesa de trabalho, ao mesmo tempo que reproduz, em gravuras, o que observa. O espaço de produção artística de Posada aparece, nessa imagem, povoado por figuras ligadas ao movimento operário, incluindo o principal nome do anarquismo mexicano do período revolucionário, Ricardo Flores Magón, em uma menção à suposta participação de Posada no periódico anti-porfirista El Hijo del Ahuizote.

Essa imagem do artista popular como um crítico social e politicamente comprometido com a Revolução de 1910 foi, de fato, a predominante por décadas nos estudos sobre sua obra. Mas, recentemente, é possível observar uma tendência a repensar essa visão de Posada. Sem dúvida, uma obra central para o desenvolvimento dessa nova tendência é o livro do caricaturista mexicano Rafael Brajas Durán (conhecido como el

\footnotetext{
${ }^{6}$ Rafael Barajas Durán desenvolve uma ampla explicação a respeito dessa construção. Ver: BARAJAS DURÁN, 2009, capítulo I.

${ }^{7}$ Imagem disponível no site do Art Institute de Chicago: https://www.artic.edu/artworks/222760/posadain-his-workshop-homage-to-posada
} 
fisgón), Posada: mito y mitote (2009). Nesse livro - verdadeiramente impressionante pelo volume de material reunido, contando com a catalogação e análise de mais de 300 imagens, em sua grande maioria produzidas por Posada-, o autor se propõe precisamente a desconstruir a imagem de Posada criada pelos "mitoteros", "los hacedores de mitos", ou seja, os artistas plásticos mexicanos de várias décadas atrás. El fisgón desmente, por exemplo, a ideia de que Posada teria colaborado com El Hijo del Ahuizote ou participado da mobilização dos Clubes Liberais. ${ }^{8}$ Argumenta, ao contrário, que o fato é que Posada colaborou com publicações hostis a periódicos anti-porfiristas e critica: "la afirmación de que Posada colabora con El Hijo del Ahuizote no tiene sustento alguno; sin embargo, hasta la fecha muchos estudiosos siguen repitiendo, sin aportar prueba alguna, que Posada es [su] colaborador." (BARAJAS DURÁN, 2009, p. 35)

Como ocorre geralmente com propostas de desconstrução de mitos, o que o autor acaba nos entregando é uma imagem invertida daquela formulada pelos que identifica como "mitoteros". Saímos de um Posada revolucionário para chegar a um Posada reacionário cuja obra, na visão de el Fisgón, revela sua "lealdade política a Porfirio Díaz." Sem conseguir negar completamente o caráter crítico da obra do artista popular, o autor afirma que este "hace una crítica suave que le resulta funcional al régimen [porfirista]"; que, mesmo em sua participação na prensa obrera de a centavo, o artista popular é "feroz en su denuncia contra los excesos patronales, pero moderado en sus críticas al régimen; apoya a la clase trabajadora, pero está contra el enfrentamento directo y los métodos violentos, pues privilegia la paz, el progreso y el orden sobre todo lo demás"; em consequência, no período revolucionário Posada "hace oídos sordos a las razones profundas de los revolucionarios que claman por la democracia y la justicia social." (BARAJAS DURÁN, 2009, p. 158; 222, 397-8)

O que realmente chama a atenção em todo esse imbroglio em torno da dimensão política de Posada é que tanto a construção quanto o desmonte do "mito" são obras

\footnotetext{
${ }^{8}$ Sobre a importância dos Clubes Liberais, fundados a partir de 1900, para o início de uma mais forte e organizada mobilização político-intelectual de oposição ao porfirismo como parte do movimento mais amplo que levaria a sua derrubada em 1910, ver: COCKCROFT, James. Precursores intelectuales de la Revolución Mexicana. México: Siglo XXI, 1971.
} 
fundamentalmente de artistas, de Rivera a el Fisgón. Atualmente, a obra deste último é, muitas vezes, tomada como a última palavra sobre o assunto, mas acreditamos que o tema ainda merece outras análises que sejam embasadas no rigor metodológico do métier historiográfico. Em grande medida, as conclusões às quais chega el Fisgón sobre o posicionamento político de Posada são derivadas de sua leitura limitada das fontes, principalmente no que se refere a uma questão central: identificar a obra gráfica do artista à posição política dos produtores das publicações nas quais se encontram suas gravuras e, sobretudo, aos textos que normalmente as acompanham.

Sobre a relação entre imagens e textos nos estudos sobre a obra do artista popular, Bonilla (2005) afirma que "uno de los grandes problemas de la historiografia fue que a lo largo de muchos años trató de interpretar el material [produzido por Posada] sin acudir a los textos." (BONILLA, 2005, p. 416) Parece-nos, de fato, que a interação entre ambos os discursos (escrito e visual) ainda precisa ser analisada com mais cuidado, posto que foi precisamente a percepção da existência de uma flagrante contradição entre as gravuras de Posada e os textos que as acompanham em diversas hojas da imprensa de Vanegas Arroyo o que nos chamou a atenção e motivou a escrita deste artigo.

\section{Posada e a política: a imagem contra o texto}

Posada colaborava com a imprensa de Vanegas quando da intensificação da oposição política ao porfiriato e início da Revolução de 1910, por isso boa parte de sua obra nas hojas populares tem uma relação muito clara com o momento político, sendo essas fontes, portanto, extremamente ricas para pensarmos a relação do artista com a política. O que se pode perceber ao analisar conjuntamente imagens e textos, mas problematizando a relação entre ambos, é que o artista foi capaz de comunicar ao público, por meio das ilustrações, um discurso (político) próprio, relativamente independente daquele que era veiculado textualmente nas mesmas hojas que ilustrava.

Isso pode ser observado mesmo em um tipo de hoja popular de caráter informativo, a Gaceta Callejera, que começou a ser editada pela imprensa de Vanegas Arroyo em 1892, sempre ilustrada por Posada, na qual, aparentemente, as imagens 
cumpriam a função da fotografia nas reportagens dos grandes diários. A Gaceta guardava uma forte aproximação temática e discursiva com a grande imprensa, reproduzindo, inclusive, o mesmo tom de pretensa imparcialidade e objetividade dos fatos: "De todo punto imparciales en la cuestión, nos limitamos a dar a conocer al público los acontecimientos que ocurran, puramente como relatores de los hechos", afirmavam os editores. (Gaceta Callejera, $n^{\circ}$ 1, maio de 1892) A explicação que davam para a veiculação de tal tipo de impresso aparecia na frase que acompanhava o título da publicação: "Esta hoja volante se publicará cuando los acontecimientos de sensación lo requieran."

$\mathrm{Na}$ época do surgimento da Gaceta os "acontecimentos de sensação" estiveram bastante relacionados ao mundo político, particularmente às mobilizações contra a reeleição de Porfirio Díaz, que já começavam a se esboçar. Como seria de suspeitar, a abordagem pretensamente imparcial e objetiva dos editores vai progressivamente revelando seu lugar de fala, como denota o seguinte comentário:

\footnotetext{
El asunto de la reelección sigue originando disturbios y escándalos que además de tener en continua sosobra [sic] a las gentes pacíficas, perjudican profundamente a los comerciantes [...]. Las calles se veían casi solas y la poca gente que transitaba, lo hacía demostrando el justificado temor de encontrarse repentinamente envuelta en un disturbio popular. (BARAJAS DURÁN, 2009, p. 120)
}

Como se pode observar no fragmento citado, que se refere à primeira edição da Gaceta callejera, as grandes preocupações manifestadas pelos editores referiam-se ao funcionamento do comércio e ao perigo de um tumulto popular. Ambas parecem remeter claramente ao lugar social de donos de uma imprensa-empresa, muito mais que expressar preocupações típicas dos setores populares. Mas, sem dúvida, a veiculação impressa desse discurso escrito tendia a moldar entre os consumidores - especialmente os leitores - das hojas uma determinada interpretação da realidade que procurava se legitimar como objetiva e imparcial.

De uma forma geral, o discurso editorial das hojas populares da imprensa de Vanegas, expresso por meio dos textos escritos, demonstra uma visão de mundo bastante conservadora, marcada pela defesa da estrutura política (no caso, a ditadura porfirista) e da ordem social. No entanto, os textos escritos não representavam a totalidade do discurso 
veiculado pelas hojas. Em todas elas as ilustrações ocupavam um espaço bastante significativo e, como demonstramos a seguir, permitiam uma "leitura" diferenciada em relação ao texto. Mesmo no caso específico da Gaceta Callejera, em que as imagens parecem demonstrar os fatos narrados, a semelhança entre os textos escritos pelo editor e as ilustrações de Posada é apenas aparente.

Na segunda edição da Gaceta callejera, os editores apresentaram ao público o que consideravam como "escândalos" derivados do movimento liberal anti-porfirista; a ênfase recaiu, então, sobre a suposta desordem do movimento. Segundo os editores do impresso, em um discurso público sobre a não-reeleição teria havido um "motim de estudantes" oriundos da Escuela Nacional Preparatoria, tendo sido necessária a intervenção policial para conter o tumulto. Nesse contexto, afirmam, "algunos soldados de la Gendarmería montada que trataron de dissolver las masas fueron apedreados." (Gaceta Callejera, ${ }^{\circ}$ 2, maio de 1892) Mas, na mesma hoja, ocupando cerca de metade do impresso, a ilustração de Posada mostra uma manifestação organizada e pacífica, composta majoritariamente por pessoas das classes média e alta (identificadas por suas roupas e chapéus), na qual não há qualquer referência à polícia. (Imagem 3) 
Imagem 3 - Gaceta Callejera, $\mathbf{n}^{0}$ 1, mayo de 1892 - El motín de los estudiantes

MEXIOO, MAYO TIE 1892

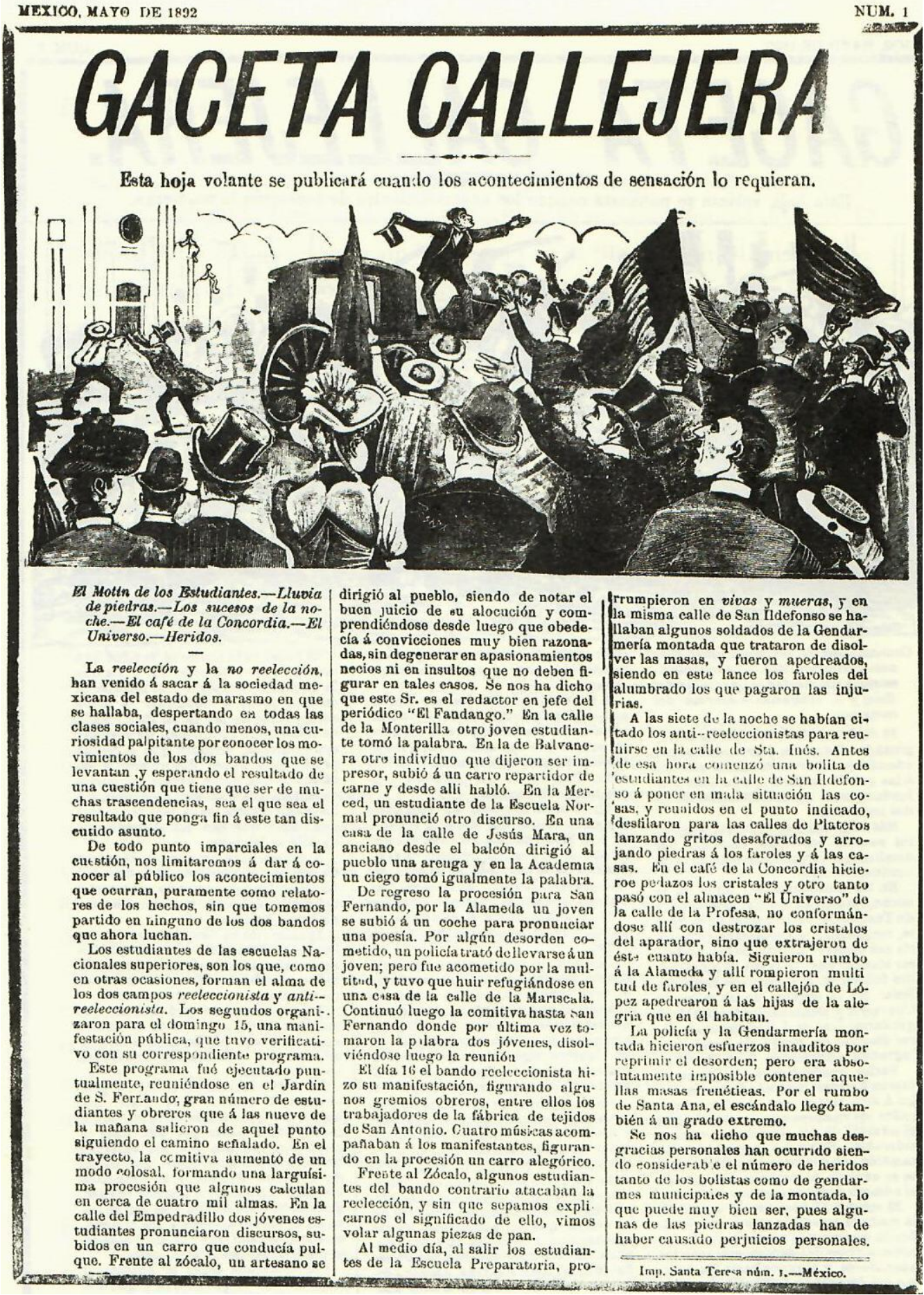

Gaceta Callejera (hoja suelta). México, D.F., Imprenta de Antonio Vanegas Arroyo, 1892. Imagem do acervo do Museo José Guadalupe Posada, Instituto Cultural de Aguascalientes.

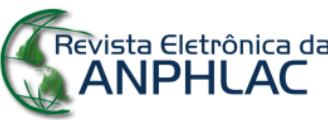

Revista Eletrônica da ANPHLAC, ISSN 1679-1061, № 29, p.444-483, Ago./Dez., 2020.

http://revista.anphlac.org.br 
Na já citada $1^{a}$ edição da Gaceta, na qual se menciona que "el asunto de la reelección sigue originando disturbios y escándalos", os editores chegam a afirmar que "varios gendarmes de la montada fueron heridos" por um "grupo de revoltosos." (Gaceta Callejera, s/d.) No entanto, a ilustração de Posada apresenta um quadro inverso, em que sobressai a violência por parte dos soldados. Montados em cavalos e portando espadas, na imagem los gendarmes repelem brutalmente os manifestantes, representados como populares de origem camponesa, com suas vestimentas e chapéus característicos. (Imagem 4)

Imagem 4 - Gaceta Callejera, $\mathbf{n}^{0}$ 2, mayo de 1892 - Continuación de las manifestaciones anti-reeleccionistas

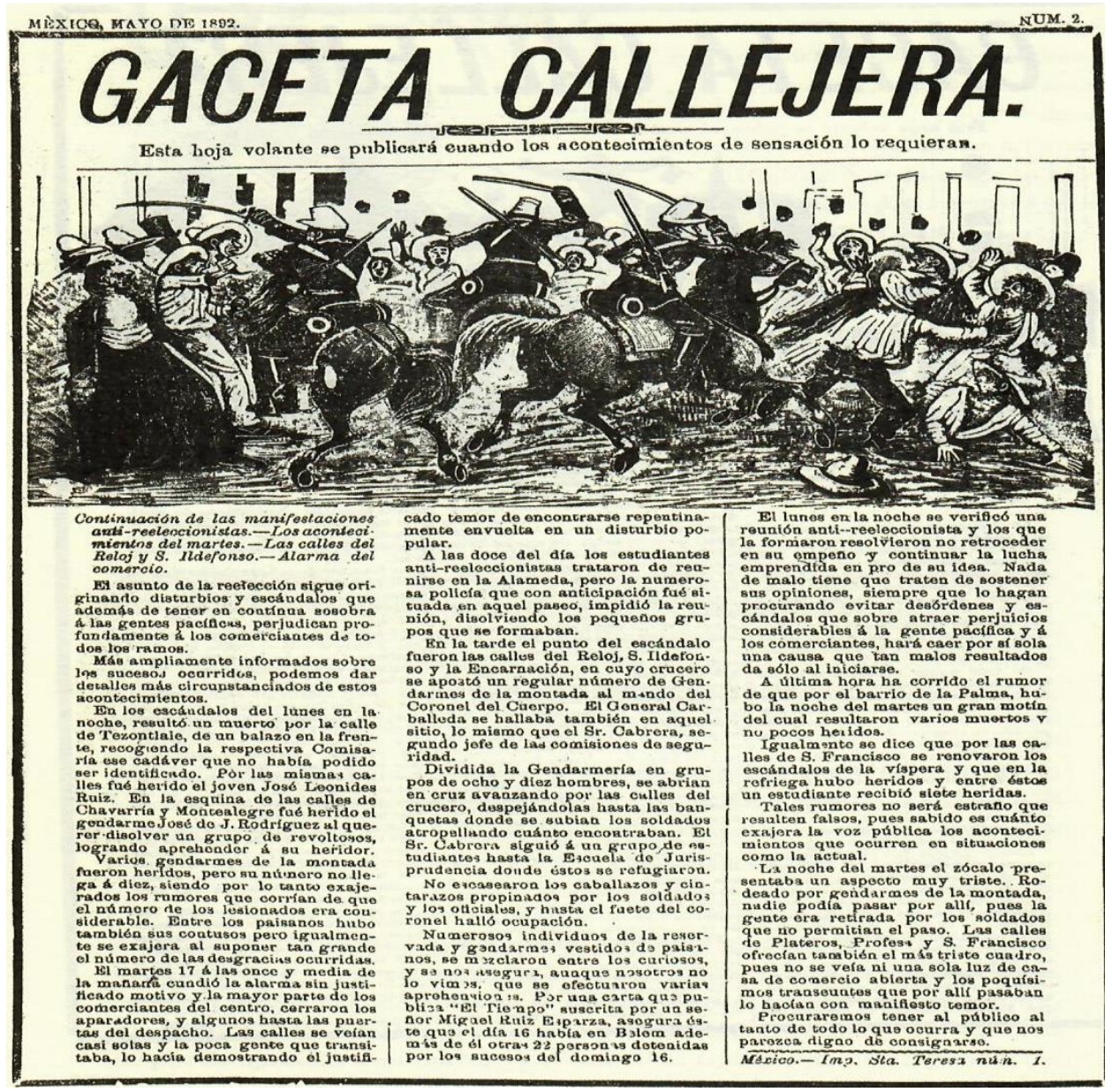

Gaceta Callejera (hoja suelta). México, D.F., Imprenta de Antonio Vanegas Arroyo, 1892. Imagem do acervo do Museo José Guadalupe Posada, Instituto Cultural de Aguascalientes.

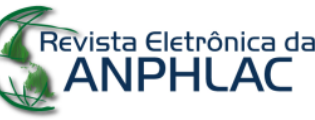

Revista Eletrônica da ANPHLAC, ISSN 1679-1061, № 29, p.444-483, Ago./Dez., 2020. http://revista.anphlac.org.br 
Não parece exagerado afirmar que nessas duas intervenções do artista popular, é possível "ler" um discurso visual - absolutamente dissonante do escrito - favorável ao movimento anti-reeleição, expresso ao se veicular uma representação pacífica da mobilização política e reforçar a imagem repressiva da ditadura, particularmente conhecida pelos setores populares, que eram os principais interlocutores do artista popular e também, certamente, as principais vítimas da ação policial porfirista.

Após o início do movimento revolucionário, em 1910, Posada veiculou uma representação bastante peculiar do líder revolucionário Francisco Madero, a partir de um temático de grande sucesso da editorial de Vanegas Arroyo, chamado "Calaveras del Montón", no qual Madero aparece sob a forma de uma calavera (Imagem 5). O texto escrito, um corrido, que acompanhava a ilustração, apresentava um tom nada entusiasta em relação ao maderismo, como se lê nos seguintes versos:

No corras tanto Madero / Deten un poco tu trote, / Porque con ese galope / Te volviste narangero. / [...] / Madero, en esta ocasión / Es mucho lo que has corrido / Perdiste ya la razón, / Y en muerte te has convertido. / [...] / Adonde está tu viveza, / Millonario con dinero, / Alza un poco la cabeza / Y dale vuelta al tintero, / Te llevan á la prisión / Más corriendo que de prisa, / [...]. (Calaveras del Montón, $\mathrm{n}^{\circ}$ 2, 1910. Grafia mantida conforme o original.)

O texto verbal apresentava, assim, a atitude do líder revolucionário como insensata e arriscada. Além disso, o autor do corrido reproduz, de forma sutil, uma das críticas mais correntes da oposição anti-maderista, ao destacar que Madero era um hacendado, "milionário". Mas, na mesma hoja, o que seria possível "ler" atendo-se à ilustração de Posada? 
Imagem 5 - Calavera de Francisco Madero

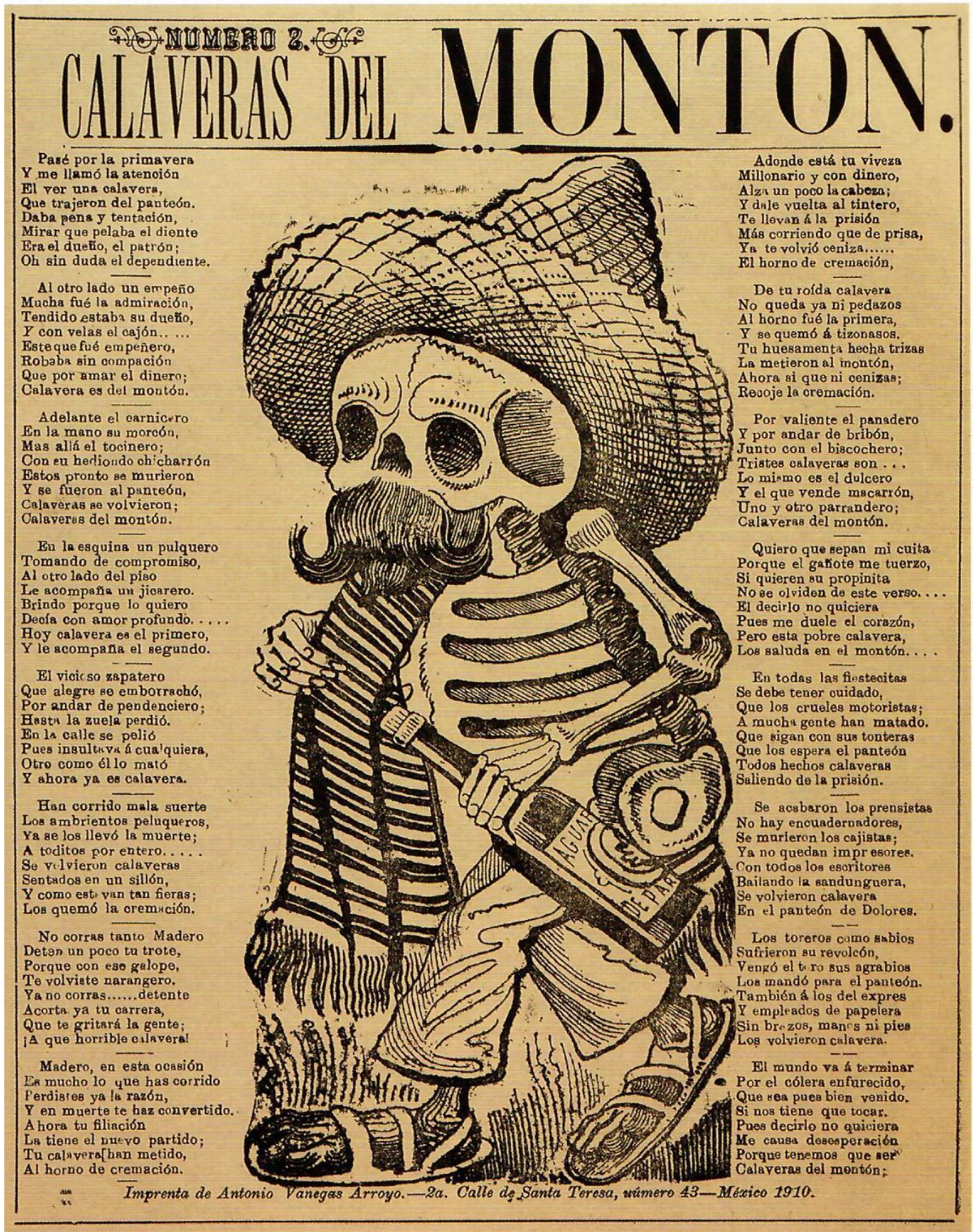

Calaveras del Montón (hoja suelta). México, D.F., Imprenta de Antonio Vanegas Arroyo, 1910. Imagem do acervo do Museo Nacional de la Muerte, Aguascalientes-México.

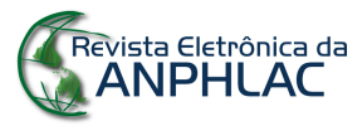

Revista Eletrônica da ANPHLAC, ISSN 1679-1061, № 29, p.444-483, Ago./Dez., 2020.

http://revista.anphlac.org.br 
Por mais incoerente que possa parecer, o artista representou a calavera de Madero como um popular, portando a indumentária típica das populações pobres rurais e semirurais mexicanas. A calavera de Madero levava um sombrero na cabeça, sarape pendurado no ombro, os pés calçados por um huarache e trazia na mão uma garrafa de aguafuerte. $\mathrm{O}$ fato de Madero-calavera ser apresentado como um bêbado cambaleante, poderia ser interpretado como uma crítica a seu suposto caráter ébrio, especialmente se esse discurso se dirigisse a grupos sociais mais ligados ao discurso oficial positivista da ditadura porfirista e sua perspectiva higienista. No entanto, não podemos perder de vista que esses impressos eram destinados justamente àqueles setores (populares) criticados pelos científicos de plantão por suas borracheras. ${ }^{9}$ A respeito, vale destacar que praticamente todas as representações dos tipos populares de Posada aparecem balizadas pelos elementos da bebida e/ou da dança, sendo que o próprio artista popular era conhecido por apreciar largamente bebidas alcoólicas.

Ora, era algo de conhecimento geral que Madero provinha dos altos estratos sociais, no entanto, Posada preferiu ilustrá-lo munido dos principais ícones do universo popular mexicano. Em primeiro lugar, essa imagem certamente era geradora de risos, tendo em vista seu aspecto absolutamente contraditório com o real. Ao mesmo tempo, essa representação de Madero permitia aproximar, a princípio visualmente, o líder revolucionário (e consequentemente o movimento por ele encabeçado) dos grupos populares. Sendo de conhecimento geral que Madero não era pobre, sua calavera popular pode ser vista, inclusive, como uma alusão ao caráter interclassista das reivindicações por ele levantadas. Por fim, a representação do líder revolucionário como um bêbado cambaleante, andando lentamente, expressa o extremo oposto do texto verbal do corrido que acompanhava a imagem de Posada na hoja popular. Se no texto escrito se afirmava que o "galope" de Madero parecia muito rápido e sugeria-se que não corresse tanto, a ilustração indicava (criticava?) um passo lento e cambaleante.

\footnotetext{
${ }^{9}$ Sobre o discurso antialcoolismo dentro da perspectiva higienista do porfiriato e sua caça às "patologias sociais", ver: PICATTO, 1997.
} 
Em 1911, quando Francisco Madero entra vitorioso na Cidade do México, após a derrubada de Porfirio Díaz, a imprensa de Vanegas Arroyo muda completamente seu discurso em relação ao líder revolucionário e publica uma hoja intitulada "Gran marcha triunfal'. Nela Madero é aclamado, nos versos que acompanham a gravura de Posada, como "redentor, más augusto de Américal [...] Que de México ha extirpado/ La ponzoña de un cruel Dictador." (Imagem 6)

\section{Imagem 6 - Gran marcha triunfal}

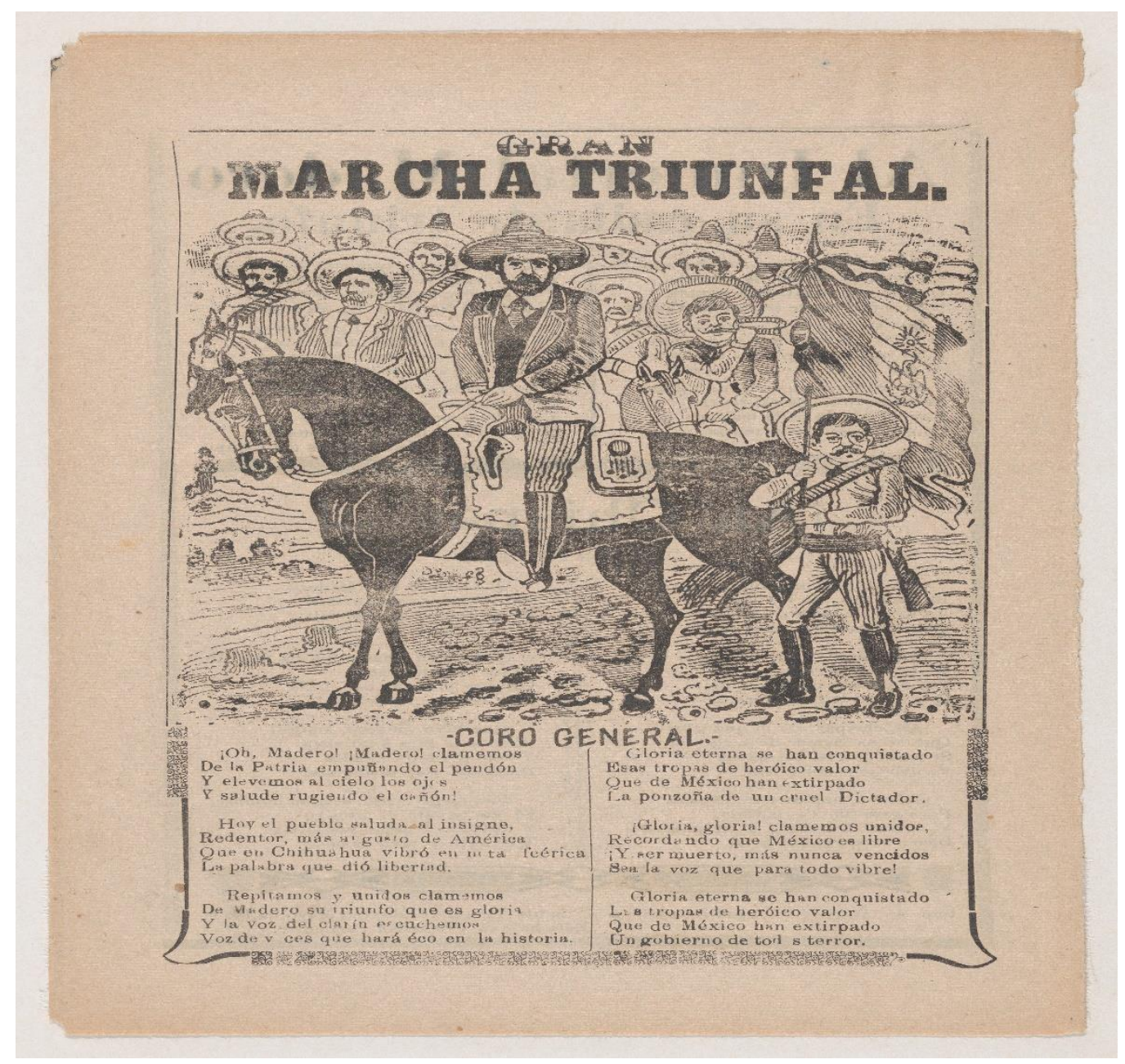

Gran marcha triunfal (hoja suelta). México, D.F., Imprenta de Antonio Vanegas Arroyo, 1911. Imagem de domínio público reproduzida da página do Metropolitan Museum of Art de Nova York: https://www.metmuseum.org/art/collection/search/717892 
Como geralmente acontece, o que realmente chama a atenção nesse impresso é a ilustração, que ocupa cerca de $2 / 3$ da folha. A imagem, da autoria de Posada, não deixa de ilustrar a entrada triunfal de Madero na capital mexicana; a figura desse líder revolucionário é, de fato, a que ocupa o lugar central na imagem. No entanto, o que mais se destaca nessa ilustração de Posada é que Madero aparece cercado de uma multidão de pessoas, que incluem tanto homens bem trajados quanto simples camponeses, com seus sombreros característicos e levando cartucheiras no peito. Mais significativo ainda é o fato de a figura de Emiliano Zapata aparecer destacada dessa multidão, colocada na dimensão mais frontal da imagem, à frente inclusive da representação de Madero. Na imagem de Posada, é Zapata, não Madero, quem carrega a bandeira mexicana.

Lembremos que a essa altura dos acontecimentos revolucionários no México os zapatistas ainda eram aliados de Madero e Emiliano Zapata ainda não havia se erigido como o líder revolucionário autônomo que, em breve, viria a ser. Mas na representação de Posada este já aparece como uma liderança não apenas importante, mas central para a vitória da Revolução. E não apenas o líder Zapata, mas a multidão de revolucionários, formada por pessoas de diferentes estratos sociais, ganha espaço na versão da "marcha triunfal" de Posada, embora não seja mencionada no texto que a acompanha.

Em relação ao líder camponês Emiliano Zapata, também chama muito a atenção a maneira específica como Posada o retratou em uma outra hoja suleta da imprensa de Vanegas, cerca de um ano depois, em 1912. Diferentemente do que ocorria na maior parte das ilustrações do artista popular, nesse caso é perceptível que ele reproduz a imagem de uma fotografia, que havia sido produzida na época e que acabou se tornando um ícone mundialmente conhecido do líder revolucionário camponês. ${ }^{10}$ (Imagem 7)

\footnotetext{
${ }^{10}$ Trata-se da famosa fotografia tradicionalmente atribuída ao fotógrafo alemão Hugo Bhreme, mas que atualmente, segundo estudos recentes realizados pelo Instituto Nacional de Antropología e Historia, do México, foi atribuída a um dos seguintes fotógrafos estadunidenses: F. Moray ou F. McKay. Sobre o assunto, consultar o site do INAH no link: https://www.inah.gob.mx/boletines/2299-brehme-y-foto-zapata
} 
Imagem 7 - La jeringa de Zapata

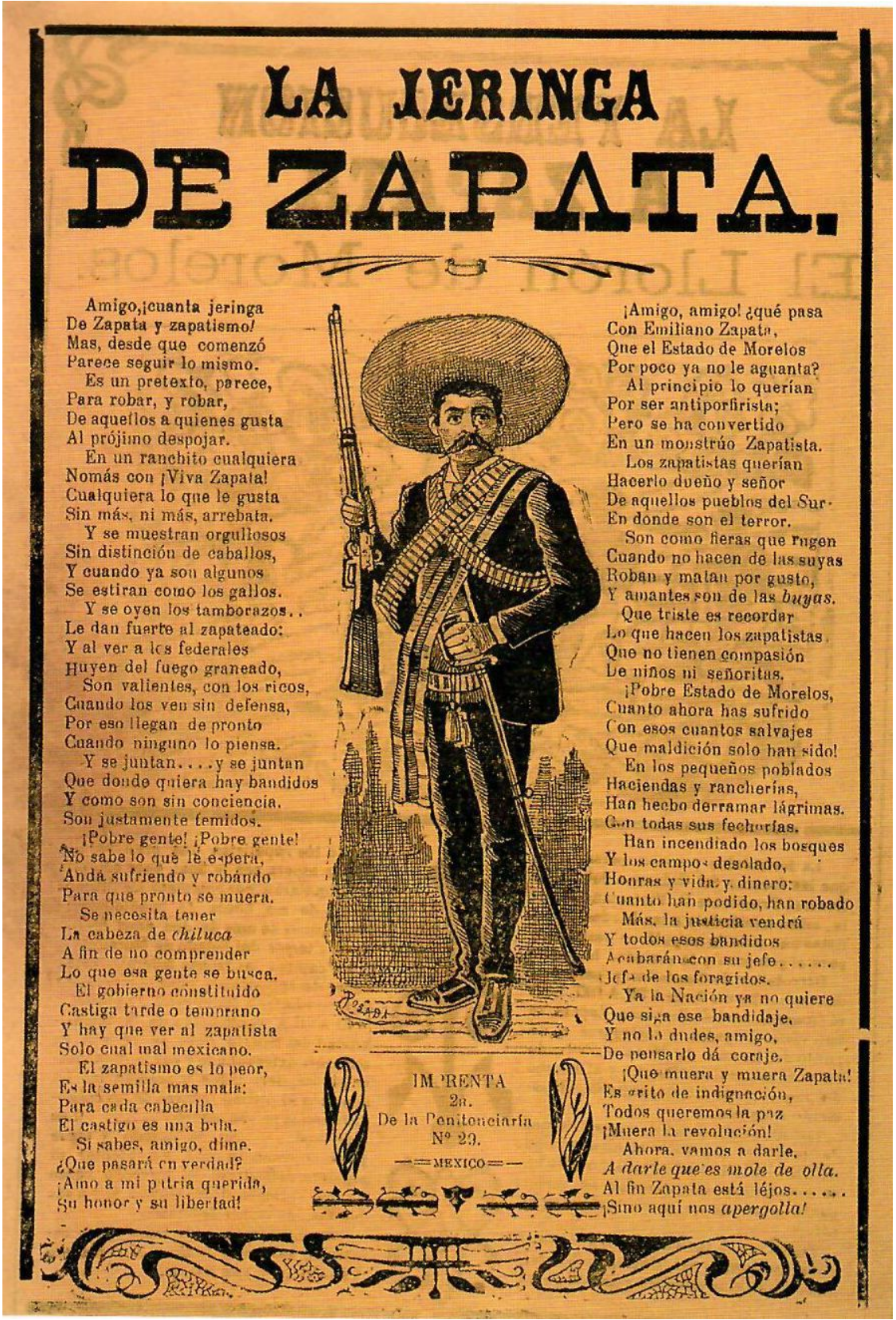

La jeringa de Zapata (hoja suelta). México, D.F., Imprenta de Antonio Vanegas Arroyo, 1912. Imagem da Colección Mercurio López Casillas.

Na tomada fotográfica, para a qual possivelmente posou (MARINO, 1998), Zapata é retratado de pé, elegantemente vestido, portanto seus característicos sombrero e fusil, cartucheras cruzadas no peito, adornado ainda por uma faixa ao estilo de uma

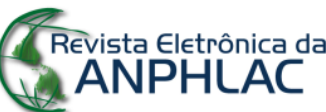

Revista Eletrônica da ANPHLAC, ISSN 1679-1061, № 29, p.444-483, Ago./Dez., 2020.

http://revista.anphlac.org.br 
condecoração presidencial. A postura do líder revolucionário camponês na foto (e na reprodução ilustrada por Posada) apresenta todo um aspecto de placidez que, no contexto de sua produção, poderia ser muito mais facilmente relacionada à imagem de Zapata como um "revolucionário honrado e sincero", veiculada pelo periódico anarquista Regeneración no contexto revolucionário (BARTRA, 1985, p. 321), do que à visão "contrainsurgente" que circulava na imprensa antirrevolucionária da época e descrevia os camponeses de Morelos a partir de termos barbarizantes, como "hordas", "ferozes" e “bandidos”, e seu principal líder como "o Átila do sul”. (MARINO, 1998) A ilustração de Posada era, de toda forma, completamente divergente das alusões depreciativas ao líder revolucionário camponês presentes no discurso escrito que a acompanhava na hoja ilustrada por Posada.

Nessa hoja, intitulada "La jeringa de Zapata", o texto foi escrito em forma de uma exortação a um "amigo" na qual aparecem severas críticas aos zapatistas:

\footnotetext{
Amigo, cuanta jeringa / de Zapata y zapatismo! / [...] / Es un pretexto, parece, / Para robar y robar, / De aquellos a quienes gusta / Al prójimo despojar. / [...] / El gobierno constituido / Castiga tarde o temprano / Y hay que ver al zapatista / Solo cual mal mexicano. / El zapatismo es lo peor, / Es la semilla mas mala. / Para cada cabecilla / El castigo es una bala. / [...] / iQue muera y muera Zapata! / Es grito de indignación, / Todos queremos la paz / ¡Muera la revolución! (La Jeringa de Zapata - Hoja suelta, 912. Grafia mantida conforme o original.)
}

Como se pode perceber, o tom do texto é claramente desmobilizador e apela à identificação do "amigo" como cristão, que não deve despojar "o próximo", e como cidadão, que deve ver no zapatista o maior exemplo do "mal mexicano". Além disso, alerta o "amigo" de que, mais cedo ou mais tarde, "o governo sempre castiga" e que o resultado de levantes como o zapatista é o castigo "à bala”. Em outras palavras, a partir da identificação dos camponeses revolucionários como "bandidos" que só querem "roubar e roubar" estabelece-se/legitima-se como solução à repressão violenta. Em contraste com esse quadro, a representação sóbria e respeitável de Zapata veiculada pela ilustração de Posada parece muito mais responder ao tom acusatório do texto do que "ilustrá-lo". 
Dificilmente as imagens aqui destacadas - ao contrário dos textos que as acompanham - poderiam abonar a visão de um Posada porfirista e "surdo" aos anseios e propostas dos revolucionários. Aliás, mesmo em pleno porfirismo e durante suas colaborações com órgãos elitistas, a obra do artista popular é perpassada por um incontestável discurso crítico. Um importante exemplo disso aparece em uma imagem de Posada presente no número de 23 de dezembro 1889 de La Patria Ilustrada, uma ilustração relacionada ao período natalino e intitulada "El invierno en México." (Imagens 8 e 9)

Imagem 8 - La Patria Ilustrada El invierno en México. Preparativos de Noche Buena EL INVIERNO EN MEXICO.

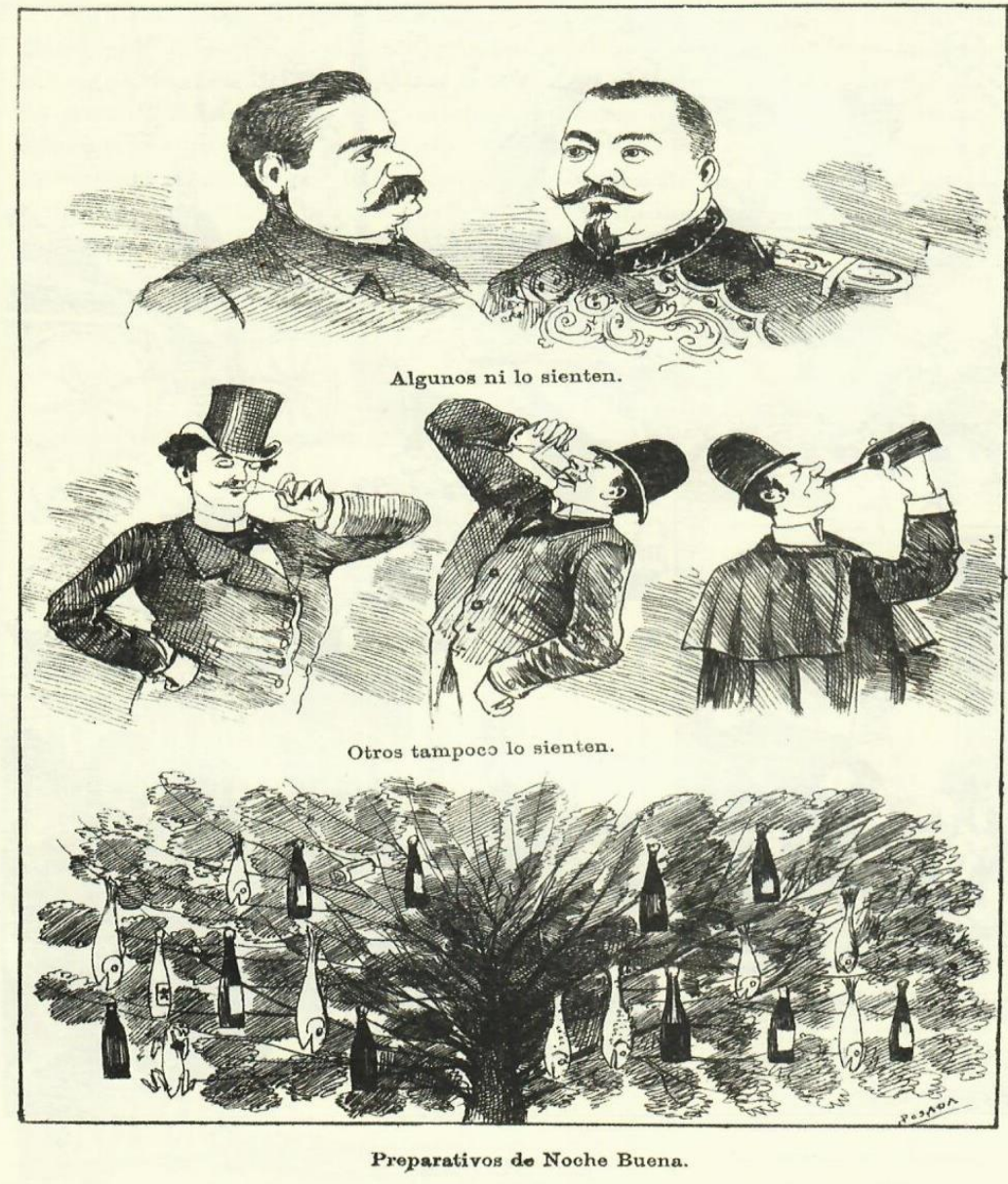

La Patria Ilustrada. México, D.F., 23/12/1889.

Imagem do acervo da Hemeroteca Nacional de México.

Imagem 9 - La Patria Ilustrada El invierno en México (continuación)

Revista Eletrônica da

ANPHLAC

Revista Eletrônica da ANPHLAC, ISSN 1679-1061, № 29, p.444-483, Ago./Dez., 2020.

http://revista.anphlac.org.br 


\section{EL INVIERNO EN MEXICO.}

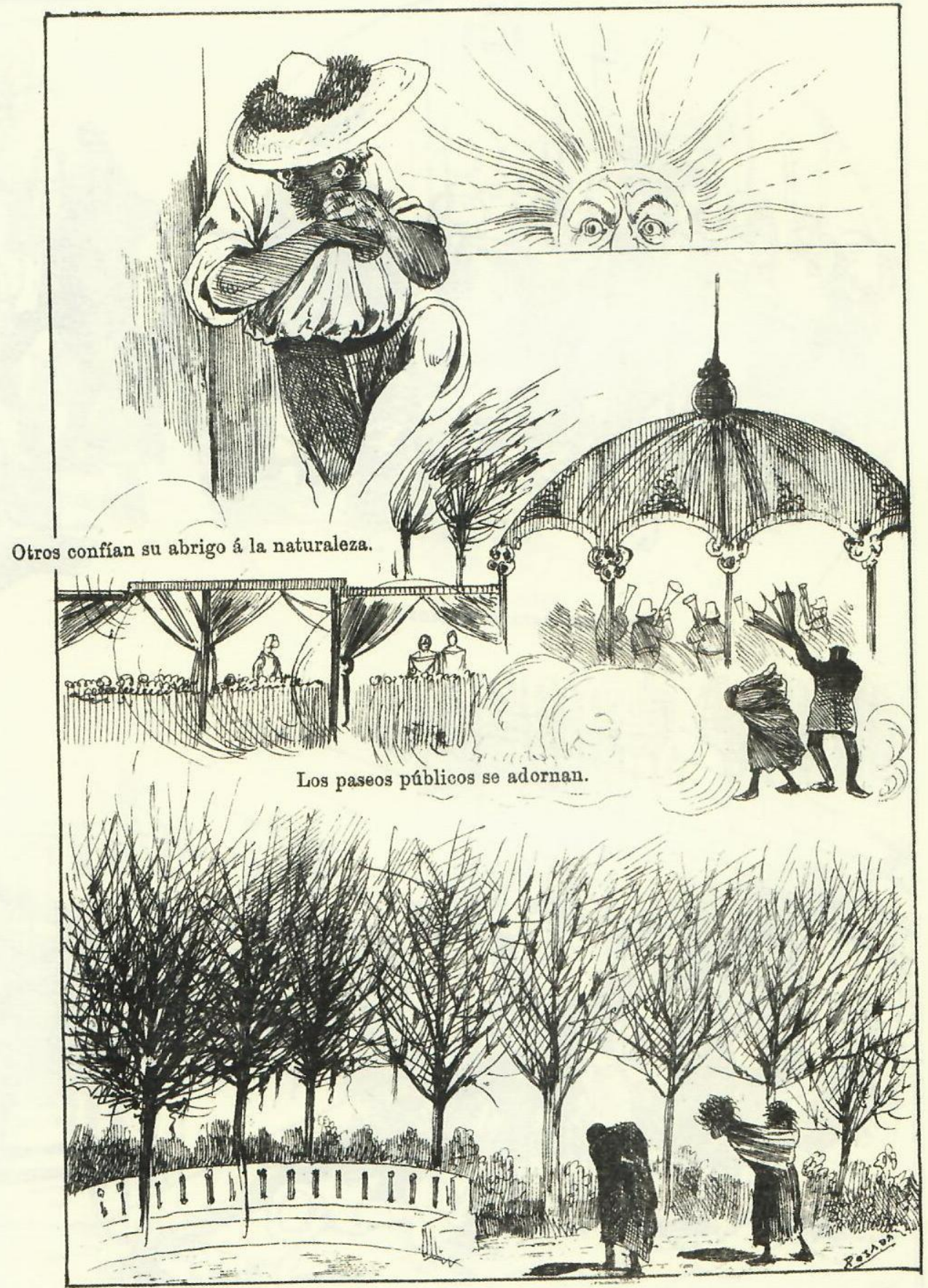

Por la Alameda no parece que pasa el invierno.

La Patria Ilustrada. México, D.F., 23/12/1889.

Imagem do acervo da Hemeroteca Nacional de México.

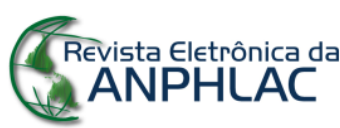

Revista Eletrônica da ANPHLAC, ISSN 1679-1061, № 29, p.444-483, Ago./Dez., 2020. http://revista.anphlac.org.br 
A partir do formato típico dos quadros costrumbistas que eram veiculados pela publicação, Posada apresentou duas estampas paralelas sobre os efeitos da chegada do inverno para as diferentes camadas da sociedade mexicana. De um lado aparecem alguns homens elegantemente vestidos (agasalhados), ingerindo bebidas. Estes, de acordo com a frase que acompanha a ilustração, "ni lo sienten", enquanto "otros confían su abrigo a la naturaleza". Essa segunda situação é representada por um tipo pobre, sem agasalho, que padece de frio ao relento. Na mesma estampa, com a mesma lógica de contraposição, o artista representou os "preparativos de Noche Buena". Do lado das elites aparece uma árvore em cujos ramos estão pendurados vários peixes e garrafas de bebidas, simbolizando a fartura; do outro lado, no quadro representativo da população economicamente menos favorecida, está ilustrada uma família pobre vagando no frio pela Alameda vazia com suas árvores desfolhadas.

$\mathrm{Na}$ maioria dos casos citados anteriormente, o discurso crítico que se pode depreender das imagens ilustradas por Posada não nos remete a um tipo mais específico de linguagem. Mas o artista popular se destacou precisamente por demonstrar grande habilidade ao utilizar-se de elementos estéticos e recursos expressivos ligados à cultura popular mexicana e, sem dúvida, o principal elemento desse discurso foram suas famosas calaveras. Elas nos colocam diante de um discurso crítico expresso por meio de uma linguagem e uma estética específica, certamente partilhada por parte dos setores populares aos quais se dirigiam esses impressos. Por meio dessa matriz discursiva, a nosso ver, Posada soube construir um particular discurso crítico, capaz de interpelar as classes populares.

\section{Las calaveras de Posada como expressão da "sensação popular do mundo"}

A proposta de Guillermo Sunkel (2016 [1985]) sobre as "matrizes culturais" discursivas em torno do popular parece-nos um importante ponto de partida para a compreensão do discurso crítico de Posada. Segundo o autor chileno, que desenvolve uma 
instigante análise a respeito do desenvolvimento dos periódicos populares de massas em seu país - desde Lira Popular, de inícios do século XX, "uma espécie de 'periodismo sem leitores"”, posto que, apesar de escrito/impresso, seu modo de difusão era fundamentalmente oral; até os diários populares massivos das décadas de 1960 e 70 -, essa imprensa popular apresentou "duas linhas de desenvolvimento" vinculadas a duas diferentes matrizes culturais: a racional-iluminista e a simbólico-dramática. A primeira matriz, derivada da modernidade política, possui como "mecanismo" de expressão a "abstração empírica" e seus elementos básicos são os conceitos, tais como razão, progresso, ilustração etc. (SUNKEL, 2016, p. 52)

Já a matriz simbólico-dramática possui uma linguagem derivada de uma visão de mundo religiosa, que representa o mundo em termos dicotômicos: o bem e o mal. De acordo com Sunkel, a estética simbólico-dramática remonta à "característica básica do imaginário [religioso barroco], que é o da dramatização das figuras." Ela provem do histórico do catolicismo colonial no Chile - o que podemos, certamente, ampliar para o caso mexicano -, mas é transformada pela cultura popular ao longo dos séculos, sendo que esta, obviamente, já não dramatiza os mesmos objetos religiosos, mas "utiliza[-se] dos mesmos meios de representação", de forma que a dicotomia bem/mal se traduz para categorias humanas, como ricos/pobres, bons/maus, generosos/avaros etc. Ainda segundo o autor, tais linguagem e estética estariam na base do "sensacionalismo" da cultura popular. (SUNKEL, 2016, p. 55-6)

Não é difícil relacionar tais percepções a boa parte da imprensa popular mexicana - como a ilustrada por Posada - de fins do século XIX e inícios do XX com suas "hojas que difundieron, recrearon o imaginaron crímenes, criminales y castigos. [...] Crímenes sacrílegos [...], homicídios pasionales", além de "hechos milagrosos o subrenaturales" $e$ hojas que "anunciaban el colapso del mundo y el juicio final." (SPECKMAN GUERRA, 2005 , p. 403; 408; 410) A proposta de Sunkel parece particularmente interessante para pensar o caráter desse sensacionalismo e talvez também possa ajudar a entender boa parte do discurso da prensa obrera de a centavo, enquanto publicações ligadas aos meios 
operários, mas cujos trabalhadores, em grande medida, partilhavam de uma visão de mundo relacionada a tal matriz cultural.

Essa perspectiva analítica poderia ser um caminho interessante para analisar os discursos sociais presentes nessas publicações, menos em termos de sua combatividade socioeconômica e política, que são noções derivadas da matriz racional-iluminista e com base nos quais, invariavelmente, seus discursos tendem a ser criticados como ideologicamente limitados e politicamente conservadores. Talvez pensá-los como parte de um discurso popular fortemente marcado pela matriz simbólico-dramática, cuja linguagem se caracteriza precisamente "pela pobreza de conceitos e pela riqueza de suas imagens" (SUNKEL, 2016, p. 54), fosse um caminho mais profícuo para uma compreensão mais complexa de seu lugar social.

Mas há uma dimensão da cultura popular, fortemente manifesta na obra de Posada e particularmente sintetizada na figura da calavera, que, em nossa concepção, extrapola a matriz simbólico-dramática derivada do universo religioso e marcada por uma visão dicotômica do mundo. Para compreendê-la, parece-nos mais útil recorrer às proposições de Mikhail Bakhtin (1993 [1965]) a respeito da "visão carnavalesca do mundo" e seu característico "riso popular".

A intensa presença das calaveras na obra de Posada é outra questão controversa. Tradicionalmente, elas foram relacionadas à cosmologia pré-hispânica e sua peculiar relação com a morte. Jesús González Aguilar sintetiza de forma bastante clara essa relação ao afirmar que "o mundo de Posada emerge da [divindade asteca] Coatlicue, mãe terra, cavidade infinita, a partir de uma visão cósmica do tempo circular." (GONZÁLEZ AGUILAR, 2007, p. 63) Mas a recente desconstrução do "mito Posada" põe em xeque também a vinculação de suas calaveras com a tradição indígena do México. Segundo el Fisgón, "se ha querido ver en las calaveras de Posada una influencia del arte prehispánico, pero es más probable que la imagen de la calavera venga de la tradición del ars morendi y de la emblemática europea." Ainda segundo o autor, Posada conhece “desde joven" toda uma "iconografía medieval y renacentista [en la que] las plagas son representadas por la muerte, um esqueleto que arrasa a los vivos com su guadaña". Além 
disso, "el tema lo toca de cerca," pois "durante todo el siglo XIX, la muerte se le aparece a los pobres de México bajo diferentes formas: em catástrofes, guerras, hambrunas y enfermidades.” (BARAJAS DURÁN, 2009, p. 97)

O grande problema desse argumento é a vinculação que estabelece da calavera com situações trágicas e negativas, quando, na verdade, nas ilustrações de Posada o que sobressai é o fato das caveiras serem alegres e jocosas, não remetendo o leitor/observador a qualquer tipo de universo mórbido, apesar de se tratar de uma representação da morte. Tal contradição é precisamente o elemento que desperta o riso. Se esse tipo de representação remonta à tradição pré-hispânica é algo a se pensar, tendo em vista, sobretudo, a centralidade da imagem da caveira desde o passado mesoamericano e sua continuidade ao longo do tempo na cultura popular mexicana, como se pode observar, por exemplo, na imensa exposição presente no Museo Nacional de la Muerte, localizado na cidade de Aguascalientes. De qualquer forma, o inquestionável é a relação das calaveras de Posada com a cultura popular de sua época - o que certamente explica o enorme sucesso de suas ilustrações. Nosso argumento é o de que essas representações expressam uma particular visão de mundo, uma "sensação popular do mundo", como chamou Makhail Bakhtin (1993), e comporta, em si mesma, uma ampla potencialidade de crítica social e política, cuja base fundamental é o próprio riso.

Consideramos que as alegres, sorridentes e dançantes calaveras de Posada podem ser tomadas como uma das melhores expressões de uma "visão carnavalesca do mundo", típica da cultura cômica popular que, como bem observou Bakhtin, “é infinita em suas manifestações" e encontra-se presente em todas as épocas históricas, ainda que reduzida a "fragmentos." Conforme desenvolvido pelo autor, essa visão de mundo possui uma linguagem e uma estética que lhe são peculiares, apesar das imensas diferenciações históricas que possa apresentar. A linguagem é a das coisas ao avesso, das paródias e degradações, e seu sentido apresenta-se como uma oposição a toda ideia de acabamento e perfeição, a toda pretensão de imutabilidade. Sua estética baseia-se no concreto/ material, contrário ao abstrato, e é marcada por um rebaixamento ao plano material e corporal. Bakhtin dá a esse conjunto estético o nome de "realismo grotesco." Realismo 
porque se refere ao real/material; grotesco porque é oposto à "estética do belo." (BAKHTIN, 1993, p. 17-8)

Toda essa tipologia de representações, em sua linguagem e estética, está profundamente articulada ao elemento básico da "cultura cômica popular", que é o "riso popular," o "riso carnavalesco," que se diferencia fortemente do riso satírico, no qual o burlador ridiculariza o outro. No riso típico da cultura popular, "todos riem, o riso é 'geral"” e "atinge a todas as coisas e pessoas;" suas propriedades básicas, segundo Bakhtin, residem nesse caráter de universalidade e também de ambivalência, pois se trata de um riso alegre e jocoso, mas também sarcástico. $\mathrm{O}$ autor destaca, ainda, como aspecto central do "riso popular," seu caráter utópico e subversivo: "devemos assinalar especialmente o caráter utópico e o valor de concepção de mundo desse riso festivo, dirigido contra toda superioridade. (BAKHTIN, 1993, p. 11-18)

Acreditamos que a representação da calavera de Posada se encaixa perfeitamente bem em toda essa descrição. Sem dúvida, a imagem do esqueleto humano apresentado, paradoxalmente, em movimento e realizando atividades das mais lúdicas e prazerosas, como beber, dançar e se apaixonar (Imagens 10, 11 e 12), nos remetem ao princípio material e corporal que caracteriza o realismo grotesco e que "aparece sob a forma universal, festiva e benfazeja" em manifestações (corporais) que "não são atribuídas a um ser biológico isolado ou um indivíduo [...], mas a uma espécie de corpo [...], coletivo e genérico.” (BAKHTIN, 1993, p. 17) 


\section{Imagem 10 - Gran fandango y francachela}

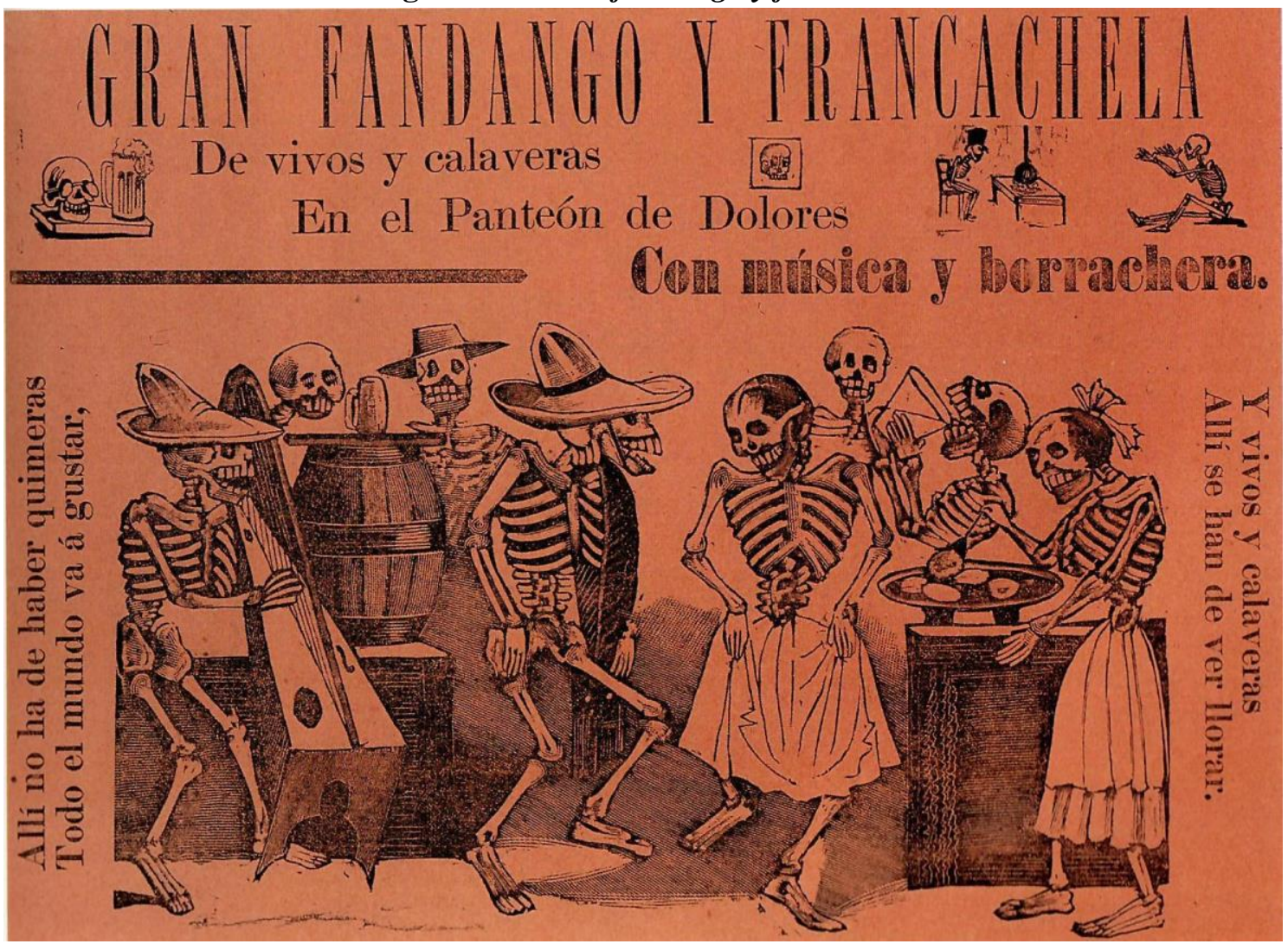

Gran fandango y francachela (hoja suelta). México, D.F., Imprenta de Antonio Vanegas Arroyo, 1892. Imagem da Colección Mercurio López Casillas. 
Imagem 11 - Coloquio de buenas calaveras
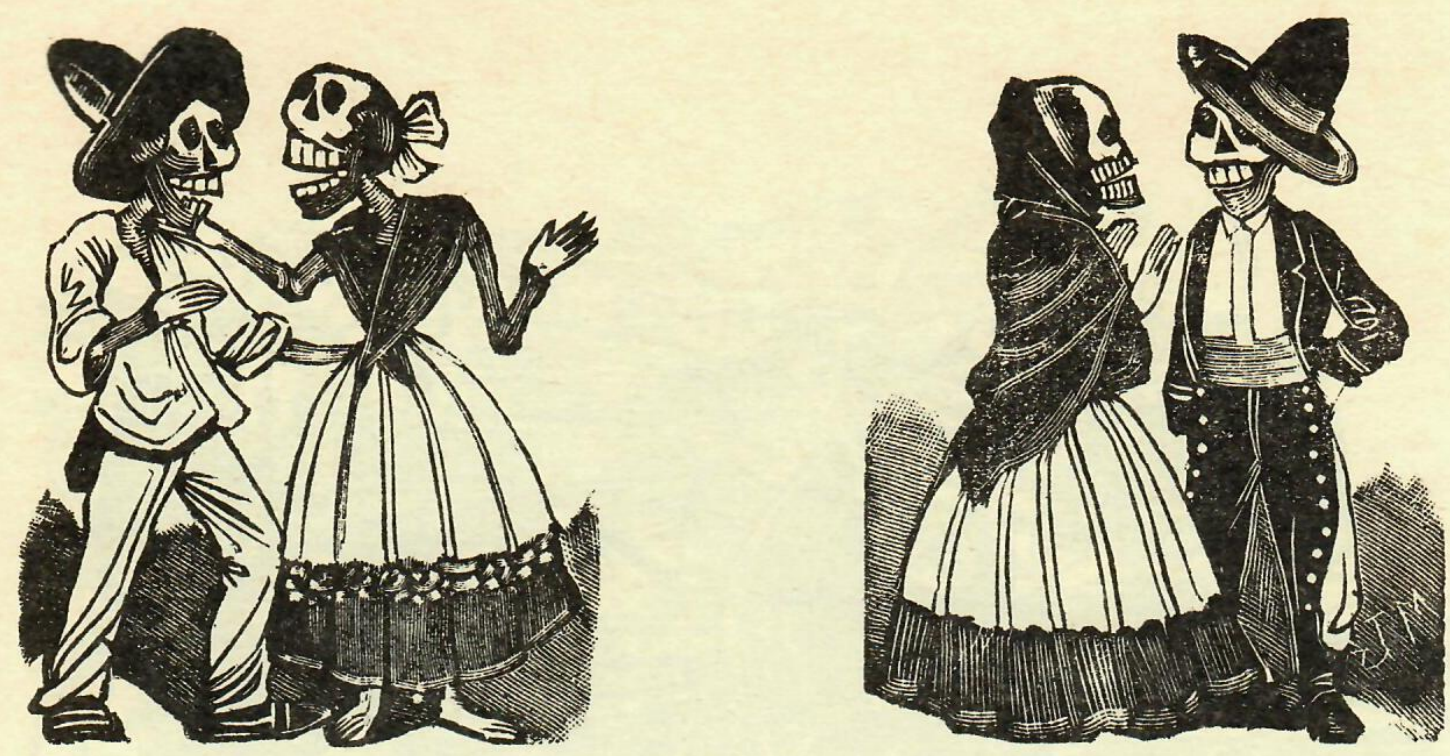

COLOQUIO DE BUENAS CALAVERAS

Coloquio de buenas calaveras (hoja suelta). México, D.F., Imprenta de Antonio Vanegas Arroyo, s./d. Imagem da Colección Andrés Blaisten. 


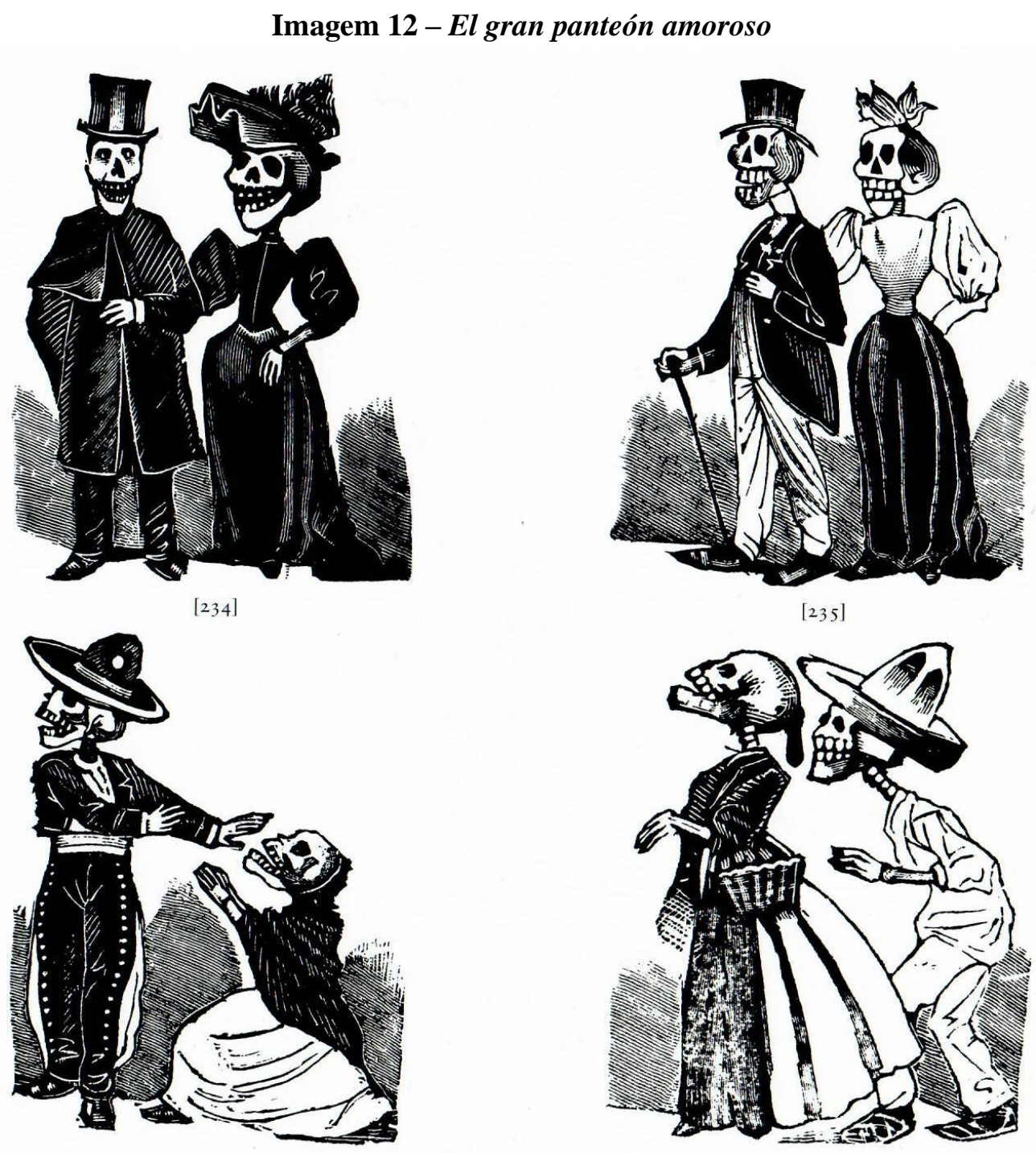

El gran panteón amoroso (hoja suelta). México, D.F., Imprenta de Antonio Vanegas Arroyo, 1894. Imagem da Colección Mercurio López Casillas.

Seria impossível imaginar um corpo mais "coletivo e genérico" que a própria caveira, representação que, ao mesmo tempo, iguala e rebaixa qualquer pretensão de superioridade: nela, populares e ricos se nivelam. Nesse sentido, as calaveras de Posada comportam um discurso que é transformador na medida em que universaliza, iguala a todos e, assim, expõe a mentira oficial: no fundo, científicos, políticos, bacharéis, camponeses, ricos, pobres, homens, mulheres.... todos não passam de caveiras. (Imagem 13) 
Imagem 13 - Calacas

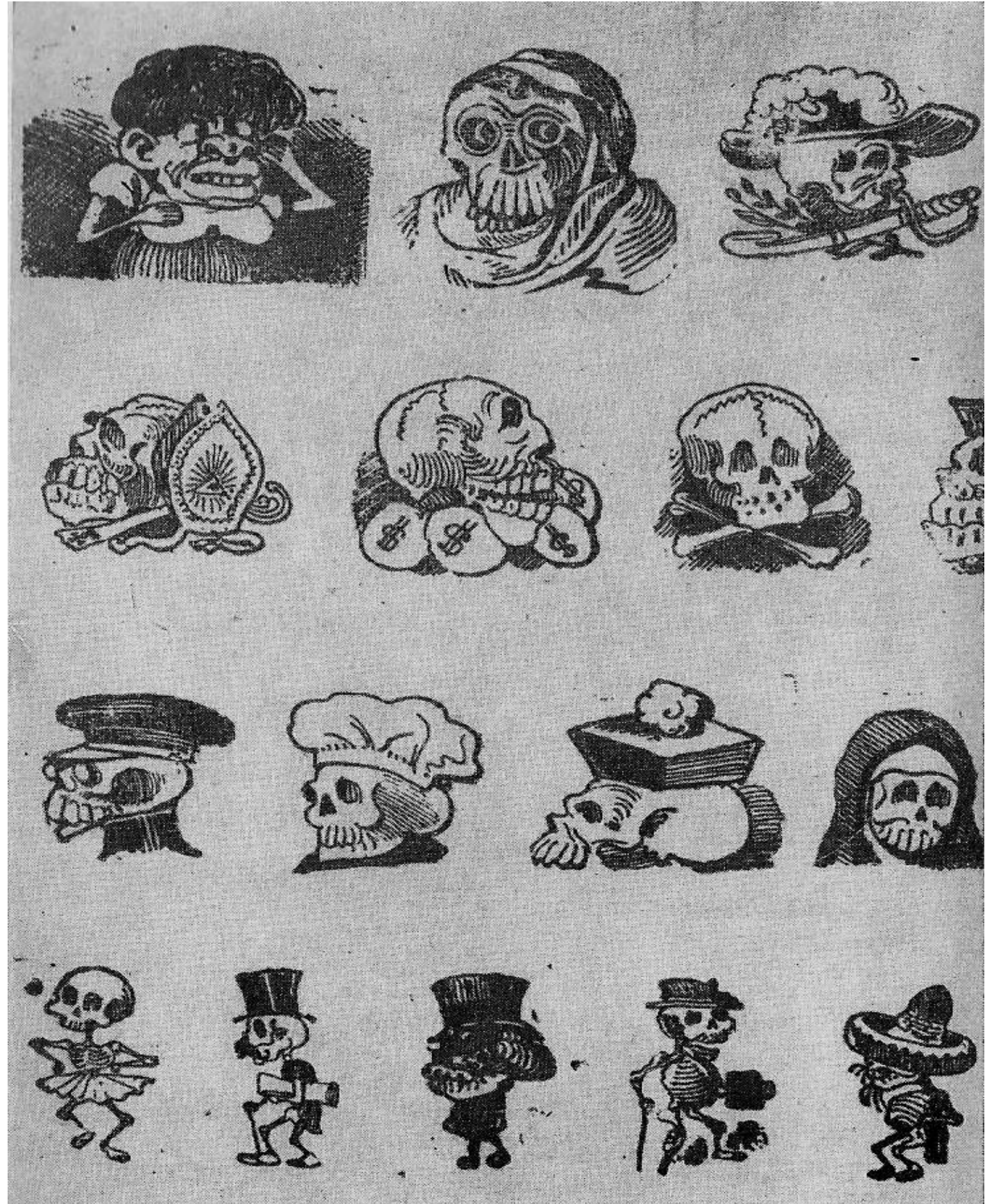

Calacas (hoja suelta). México, D.F., Imprenta de Antonio Vanegas Arroyo, s./d. Imagem da Colección Andrés Blaisten.

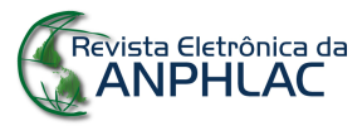

Revista Eletrônica da ANPHLAC, ISSN 1679-1061, № 29, p.444-483, Ago./Dez., 2020.

http://revista.anphlac.org.br 
Nessas representações, marcadas pelo rebaixamento ao material e corporal, característico do realismo grotesco da cultura popular, exerce-se propriamente a “degradação do sublime", identificado aos valores das classes dominantes, tais como dinheiro, poder, saber.

Em A beleza salvará o mundo, Tzvetan Todorov desenvolve uma interessante reflexão a respeito da aspiração humana ao absoluto e os perigos que envolvem a busca extrema da perfeição, estética ou política, herdeiras de uma concepção dualista que opõe um mundo real a outro ideal. ${ }^{11}$ Embora Todorov não tenha se detido na análise do cientificismo de finais do século XIX, é perceptível que os traços essenciais do "absoluto terrestre" também se insinuam na crença de que a ciência seria capaz de ordenar, desenvolver e aperfeiçoar o mundo. As teorias positivistas, evolucionistas e higienistas que caracterizaram o México porfirista se inscrevem perfeitamente naquilo que Karl Popper chamou de "sonho cativante de um mundo maravilhoso" (POPPER, 1979, p. 35 apud TODORO, 2011, p. 278), cuja base remonta à tradição dualista, à busca pelo absoluto e sublime, uma concepção de mundo, portanto, "que opõe radicalmente o baixo e o alto." (TODOROV, 2011, p. 279). Ora, o avesso, inclusive estético, dessa visão de mundo não estaria justamente no realismo grotesco e em seu aspecto de "degradação do sublime"?

As calaveras ilustradas por Posada podem adquirir, assim, uma dimensão política, que se estabelece na confrontação com a "verdade oficial". Ao aproximar conceitos distantes, unir coisas que se excluem entre si (como vida e morte), violando as noções habituais, o grotesco artístico, conforme a definição de L. Pinski (apud apud BAKHTIN,

\footnotetext{
${ }^{11}$ Segundo Todorovr, a origem da tradição de pensamento dualista remonta às doutrinas religiosas, gnosticismo e maniqueísmo, que se desenvolveram, por volta dos séculos II e III, em reação ao cristianismo; foram combatidas como heresias, mas não deixaram de influenciar a religião que se tornou hegemônica. Sendo incorporada pela tradição cristã, a concepção dualista do mundo chegou à modernidade já não mais pela via do sagrado - posto que o mundo moderno se caracteriza exatamente pela "aterrissagem do absoluto" -, mas insinuando-se nas duas formas do "absoluto terrestre": a coletiva, que envolve as utopias sociais de salvação da nação ou da humanidade; e a individual, que permeia doutrinas marcadas por um esteticismo que, desde o Romantismo, concebe a arte como "remédio" para a sociedade, a partir da transformação do indivíduo. Assim, conclui Todorov, os "maniqueísmo[s,] político e estético [...] não deixam de compartilhar uma visão parecida de mundo" e "ambos participam de um mesmo movimento histórico", cujas implicações políticas sobre o mundo contemporâneo foram devastadoras. Conforme observa, tanto as utopias românticas de perfeição artística quanto os Estados com pretensões totalitárias "provêm de uma mesma concepção de mundo". (TODOROV, 2011, p. 256; 278-9)
} 
1993, p. 29, nota 9), “se assemelha ao paradoxo lógico.” Nesse sentido, o realismo grotesco pode ser entendido como expressão de um saber que se constitui no avesso do cientificismo. Mais que um saber, podemos dizer que se trata de algo como uma "sabedoria popular", uma concepção profunda do mundo, uma "expressão artística e ideológica do poderoso sentimento da história e da alternância histórica." (BAKHTIN, 1993, p. 22) Pode-se pensar essa "sensação popular do mundo", nesse caso, do mundo social, em termos de renovação e regeneração.

Apesar de sua particular visão de mundo e expressão estética, também podemos observar certa similitude entre o sentido político encarnado por essa crítica popular condensada na imagem da calavera, no contexto do México (pré)revolucionário, com a as demais perspectivas críticas, vindas de outros estratos sociais, perante a ordem vigente. Podemos evocar aqui a noção de "circularidade cultural", mais exatamente a circularidade de uma cultura política crítica à ditadura porfirista e aos pressupostos cientificistas que a sustentavam, que perpassava diversos grupos da sociedade mexicana, mas se expressava a partir de suas diferentes concepções de mundo e linguagens específicas. Na perspectiva popular, em sua "percepção carnavalesca do mundo", o elemento realmente desafiador, revolucionário, encontrava-se no "autêntico humanismo", experimentado no contato vivo e material da praça pública, mas que também podia ser vislumbrado por meio das imagens das alegres calaveras. Ao se igualarem a todos como caveiras, as hierarquias da vida ordinária eram alteradas não como uma simples inversão dialética (pela qual os de baixo vão para o alto), mas de forma que eram questionadas as próprias categorias hierárquicas, tais como vida e morte, alto e baixo, então apresentadas em sua relatividade.

Se, como propõe Bakhtin, os grandes acontecimentos da história se desenrolam "diante do coro popular a rir" - embora, como observa, nem todos tenham "um corifeu da envergadura de Rabelais", capaz de revelar "com tal clareza, com tal plenitude, a língua original e difícil do povo" -, acreditamos que Posada foi um corifeu do coro popular da Revolução Mexicana. Nesse processo, o próprio povo também participou, mas, como em outros eventos históricos, conforme Bakhtin observa com perspicácia, o 
povo "distingu[iu]-se dos outros protagonistas pela capacidade e o direito de ter um riso ambivalente." (BAKHTIN, 1993, p. 418)

\section{Considerações finais}

Como procuramos mostrar ao longo deste trabalho, a obra de Posada em seu conjunto, antes e depois do início da Revolução Mexicana, está perpassada por um amplo e diversificado, mas coerente, discurso crítico à ordem social, o que, em tempos do porfiriato, incluía a estrutura política (ditadura) que a comportava. Mesmo - ou talvez principalmente - suas aparentemente despretensiosas calaveras alegres, sorridentes e dançantes podiam carregar um discurso crítico potencialmente subversivo, acessível àqueles que compartilhavam de uma "percepção carnavalesca do mundo", com sua linguagem e estética características.

No contexto que antecedeu a explosão revolucionária de 1910 no México, caracterizado pela intensificação da oposição política à ditadura profirista, o discurso ideológico-estético presente nas alegres calaveras de Posada pôde adquirir um sentido político de crítica à ordem dominante. A partir da estética realista-grotesca, as calaveras alegres expressavam uma visão popular - em grande medida rural, indígena e analfabeta - sobre o mundo social e político. Embasada no princípio material e corporal típico da "sensação popular do mundo", essa percepção da realidade contrastava, em sua linguagem, com as abstrações e idealizações presentes no discurso oficial, dito científico, da ditadura, bem como nos demais discursos que faziam parte da contestação ideológica ao regime, como o discurso liberal ancorado em uma liberdade abstrata e as noções da luta de classes e revolução socialista, que estruturavam a vertente revolucionária anarquista, majoritária entre as classes operárias.

Concordamos plenamente com Helia Emma Bonilla quando afirma que "la gran cantidad de bibliografia que se ha concentrado en el trabajo de este artista [Posada] permitiría suponer que ha habido un estudio profundo al respecto, pero nos es así." (BONILLA, 2005, p. 416) Este artigo - que não pretende ser mais que uma espécie de provocação acadêmica, historiográfica - foi pensado como uma pequenina contribuição, 
um grãozinho de areia, que servisse apenas para apontar como a relação de Posada com a política continua sendo uma seara a ser desbravada.

\section{Referências Bibliográficas}

BAKHTIN, Mikhail. A cultura popular na Idade Média e no Renascimento: o contexto de François Rabelais [1965]. São Paulo-Brasília: Ed. Unb-Hucitec, 1993.

BARAJAS DURÁN, Rafael. Posada, mito y mitote. La caricatura politica de José Guadalupe Posada y Manuel Alfonso Manilla. México: Fondo de Cultura Económica, 2009.

BARTRA, Armando. Regeneración, 1900-1918. La corriente más radical de la revolución mexicana de 1910 a través de su periódico de combate. México: Era, 1985.

BONILLA, Helia Emma. Imágenes de Posada en los impresos de Vanegas Arroyo. In: CLARK DE LARA, Belem; SPECKMAN GUERRA, Elisa (eds.). La república de las letras: asomos a la cultura escrita del México decimonónico. (Vol 2). México: UNAM, 2005.

GONZÁLEZ AGUILAR, Jesús. Ensor-Posada: dos expresionismos de fines del diglo XIX. Archipiélago. Revista Cultural de Nuestra América. México, UNAM, v. 14, n. 51, 2007, p. 62-3.

GUERRA, François-Xavier. México: del antiguo régimen a la Revolución. Vol. 1. México: Fondo de Cultura Económica, 2003.

LUÉVANO DÍAZ, Alain; RAMÍREZ HURTADO, Luciano. El joven José Guadalupe Posada em Aguascalientes (1868-1872): ¿al margen de la academia? In: ESTRADA RAMOS, Juan U.; JAIME ESPINOSA, María E. (coords.). Sociedad y cultura: Miradas a la modernidad, siglos XIX y XX. México: Universidad Autónoma de Tlaxcala, 2015, p. $27-43$.

MARINO, Daniela. Dos miradas a los sectores populares: fotografiando el ritual y la política en México, 1870-1919. In: Historia Mexicana, v. XLVIII, nº 2, 1998, p. 209-276.

MORENO VILLARREAL, Jaime. Posada. Aviso de hojas volantes. In: Letras libres. Enero de 2003. Disponível em: <https://www.letraslibres.com/mexico/posada-avisohojas-volantes> (Acesso em: 28/05/2019)

OROZCO, José Clemente. Autobiografía [1945]. México: Planeta, 2002. 
PICCATO, Pablo. "No es posible cerrar los ojos": el discurso sobre la criminalidad y el alcoholismo hacia el fín del porfiriato. In: PÉREZ MONTFORT, Ricardo; DEL CASTILlO, Alberto; PICCATO, Pablo. Hábitos, normas y escándalo: prensa, criminalidad y drogas durante el porfiriato tardío. México: Plaza y Valdés editores, 1997, p. $75-132$.

SODRÉ, Nelson Werneck. História da imprensa no Brasil. Rio de Janeiro: Civilização Brasileira, 1966.

PINSKI, L. O realismo na época renascentista. Moscou: Edições Literárias do Estado, 1961

POPPER, Karl. La société ouverte et sés ennemis. (Tomo 1). Paris: Le Seuil, 1979.

SUÁREZ DE LA TORRE, Laura. La producción de libros, revistas, periódicos y folletos en el siglo XIX. In: CLARK DE LARA, Belem; SPECKMAN GUERRA, Elisa (eds.). La república de las letras: asomos a la cultura escrita del México decimonónico. (Vol 2). México: UNAM, 2005. p. 9-25.

SPECKMAN GUERRA, Elisa. Cuadernillos, pliegos y hojas sueltas en la imprenta de Antonio Vanegas Arroyo. In: CLARK DE LARA, Belem; SPECKMAN GUERRA, Elisa (eds.). La república de las letras: asomos a la cultura escrita del México decimonónico. (Vol 2). México: UNAM, 2005. p. 391-413.

De amor y desamor: ideas, imágenes, recetas y códigos en los impresos de Antonio Vanegas Arroyo. Revista de Literaturas Populares. México, Facultad de Filosofía y Letras, UNAM, Ano 1, $\mathrm{n}^{\mathrm{o}}$ 2, 2001. p. 68-101. $<$ http://www.rlp.culturaspopulares.org/textos/2/05-Speckman.pdf $>$ (Acesso em: 30/05/2019)

SUNKEL, Guillermo. Razón y pasión en la prensa popular: un estudio sobre cultura popular, cultura de masas y cultura política [1985]. Santiago de Chile, El Buen Aire S.A., 2016.

TIBOL, Raquel. Apuntes estéticos y biográficos. In: La jornada semanal, n 362 de 2002. Disponível em: <https://www.jornada.com.mx/2002/02/10/sem-tibol.html> (Acesso em: 20/05/2019)

TODOROV, Tzvetan. A beleza salvará o mundo: Wilde, Rilke, Tsvetaeva, os aventureiros do absoluto. Rio de Janeiro: DIFEL, 2011.

WESTHEIM, Paul. El legado plástico de Posada. In: La Jornada, nº 361, feb. 2002. <http://www.jornada.unam.mx/2002/02/03/sem-paul.html> (Acesso em: 30/05/2019) 